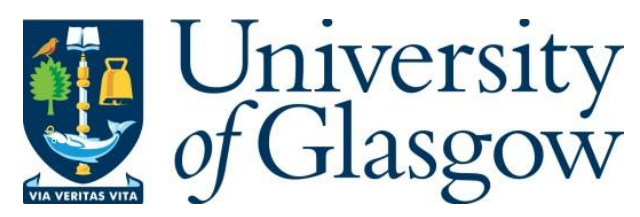

Javed, F. et al. (2019) Microalgae-based biofuels, resource recovery and wastewater treatment: A pathway towards sustainable biorefinery. Fuel, 255, 115826.

There may be differences between this version and the published version. You are advised to consult the publisher's version if you wish to cite from it.

http://eprints.gla.ac.uk/190526/

Deposited on: 25 September 2019

Enlighten - Research publications by members of the University of Glasgow http://eprints.gla.ac.uk 


\section{Microalgae-based Biofuels, Resource Recovery and Wastewater Treatment: A Pathway \\ 2 Towards Sustainable Biorefinery}

3 Fahed Javed ${ }^{\mathrm{a}, \mathrm{e}}$, Zufishan Shamair ${ }^{\mathrm{a}}$, Muhammad Aslam ${ }^{\mathrm{a} *}$, Naim Rashid ${ }^{\mathrm{a}, \mathrm{e}^{*}}$, Asim Laeeq Khan ${ }^{\mathrm{a}}$, Muhammad Yasin ${ }^{\mathrm{a}}$,

4 Tahir Fazal ${ }^{\mathrm{a}, \mathrm{e}}$, Ainy Hafeez ${ }^{\mathrm{a}, \mathrm{e}}$, Fahad Rehman ${ }^{\mathrm{a}, \mathrm{e}}$, Muhammad Saif Ur Rehman ${ }^{\mathrm{b}}$, Zakir Khan ${ }^{\mathrm{a}, \mathrm{c}}$, Javed Iqbal ${ }^{\mathrm{b}}$, Aqeel

Ahmed Bazmi ${ }^{\mathrm{a}, \mathrm{d}}$

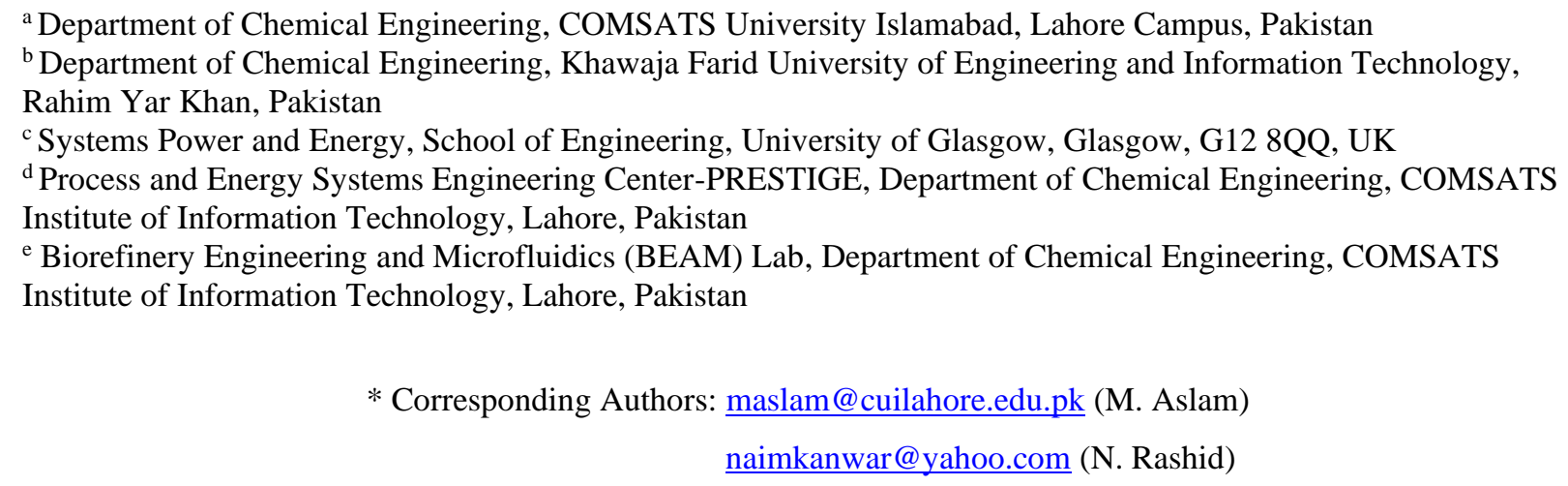

* Corresponding Authors: maslam@ @ cuilahore.edu.pk (M. Aslam) naimkanwar@yahoo.com (N. Rashid)

\section{Abstract}

18 Intense utilization of natural fuel resources is threatening the global environment and societal 19 sustainability. It triggers up the need for finding environmental-friendly and sustainable sources 20 of energy. In this perspective, microalgae have emerged as a potential alternative. Microalgae are

21 featured with distinct ability to provide ecological services and respond to the sustainability

22 challenges simultaneously. Microalgae can fix atmospheric $\mathrm{CO}_{2}$, valorize waste resources, and can

23 produce a wide variety of bio-products. The promising features of microalgae pitch the idea of

24 establishing a sustainable bio-refinery to draw multifaceted benefits and reinforce the objectives

25 of resource efficient bio-economy. Unfortunately, in the last few years, preferential studies have

26 been carried out to assess the potential of microalgae-based integrated bio-refinery. This review

27 critically discussed the recent developments, opportunities, and barriers in the microalgae bio-

28 industry and wastewater treatment. Particularly, microalgae potentials for biofuels and resources

29 recovery are addressed towards sustainable biorefinery. Moreover, techno-economic and 
1 commercial viability of microalgae-led bio-refinery is reviewed to drive this technology towards

2 practicality.

3 Keywords: Microalgae; biofuels, wastewater, biomass, biorefinery

\section{$4 \quad 1 \quad$ Introduction}

5 Urbanization, industrialization, and overuse of fossil fuels cause an increase in greenhouse

6 gas (GHG) emissions. Wastewater discharge without treatment threatens both human and

7 ecological health. It triggers up the need of exploring clean, renewable and sustainable resources

8 of energy [1-3]. Recently, research has been emphasized to use waste streams (including solid,

9 liquid and gaseous) as resources to recover and produce biofuels such as biodiesel, bio-methane,

10 bio-hydrogen, bio-oil, and other value-added products [4]. Microalgae is one of the most

11 executable biomass for industrialization without any harmful effects on the environment.

12 Microalgae can grow in fresh, waste, or sea water. Algae cultivation does not require freshwater,

13 agricultural land, and yet it has high biomass yield with large starch and oil content. Techniques

14 employing microalgae, such as anaerobic digestion to methane, microalgae oil to biodiesel and

15 photobiological conversion to hydrogen production can produce several different renewable

16 biofuels. The production of biofuel is not a new concept. However, currently it is investigated

17 more earnestly due to growing demand and increasing price of fossil fuels. However, production

18 of biofuel through microalgae is impeded by many commercialization challenges such as

19 deficiency of energy and cost-intensive processes for algae growth and harvesting with a

20 significant amounts of nutrients needed like nitrogen $(\mathrm{N})$ and phosphorous $(\mathrm{P})$, with conventional

21 cultivation methods [5]. Moreover, membrane integrated systems are emerging as potential

22 alternatives not only in microalgae cultivation and harvesting but also to produce and recover 
1 biofuels such as biogas, bio-hydrogen, biodiesel, bioethanol, and other value-added products [6-

$211]$.

3 Wastewater treatment through microalgae growth and cultivation has gained promising

4 attention as an economical and environmental-friendly route for microalgae-based biofuels

5 production [12]. For instance, algae consume nutrients that can be "procured" from wastewater

6 providing bioremediation while reducing treatment costs [12]. Integrating this with $\mathrm{CO}_{2}$ emission

7 plants would result in more efficient carbon capture and sequestration. Biomass generated through

8 this process can be used to produced biofuels and other by-products as shown in Fig. 1. Microalgae

9 cultivation in wastewater is a long-known technology. Microalgae generate oxygen through

10 photosynthesis during cultivation. The produced oxygen can be utilized to degrade organic matter

11 and bio-remediate inorganic compounds present in the wastewater. Thus, photosynthetic oxygen

12 displaces the need for providing air through conventional aeriation process reducing the cost

13 significantly. Microalgae also have an ability to recover resources from the wastewaters which

14 have promising applications in bio-refinery [13].

15 Microalgae cultivation in wastewater is a promising bio-refinery approach; however, it

16 confronts with many challenges including contamination, low biomass yield, complex nutrients

17 removal mechanism, and impurities in the biomass after downstream processing. For a sustainable

18 and economical bio-refinery, future research should be dedicated to address these challenges. This

19 review provides a perspective on recent trends and developments in microalgae-based wastewater

20 bio-refinery. The possibility of integrating the wastewater industry with microalgae cultivation and

21 biofuels production is critically reviewed. Life cycle and techno-economic analysis are also

22 presented to assess the sustainability potential of microalgae industry. 


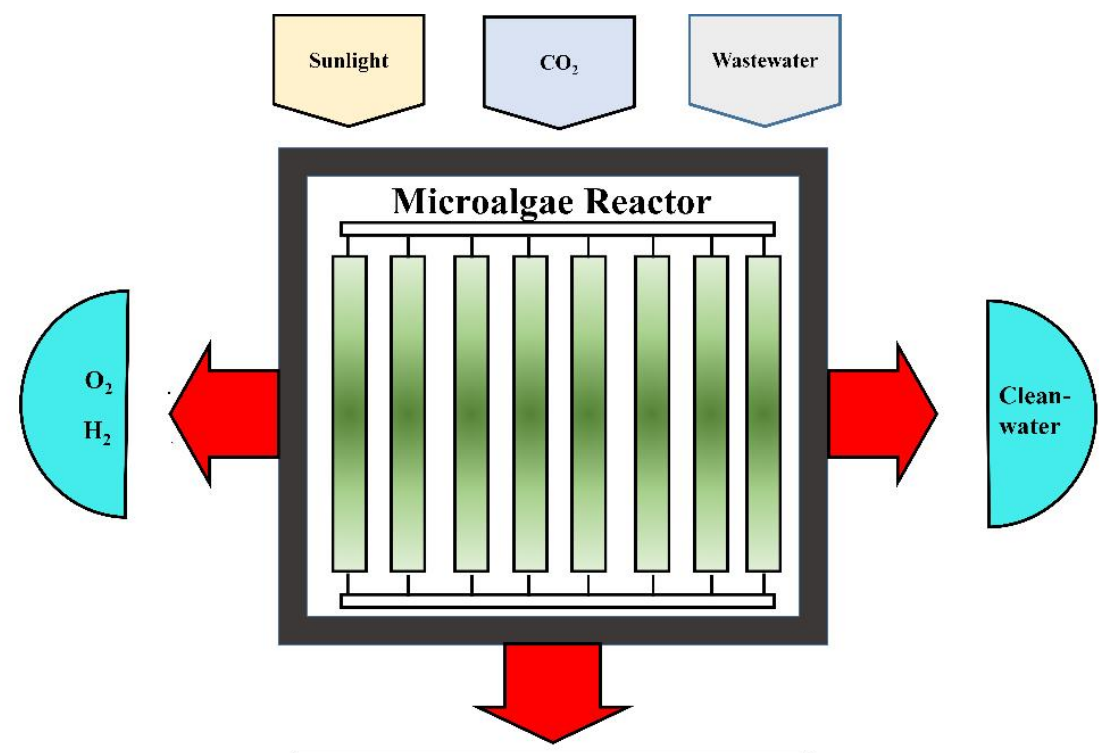

\section{Harvesting of Microalgae}

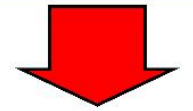

Extraction \& Separation
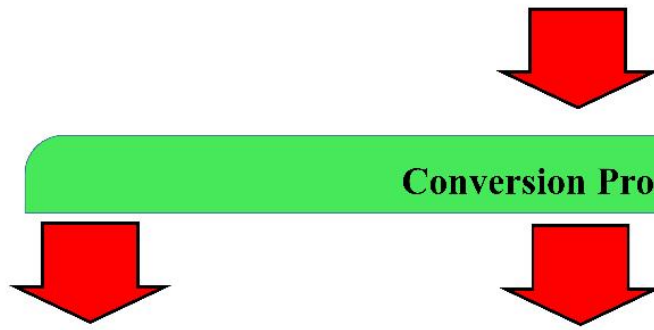

\section{Conversion Processes}

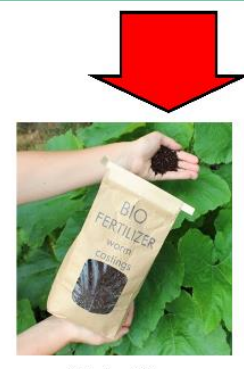

Biofertilizer
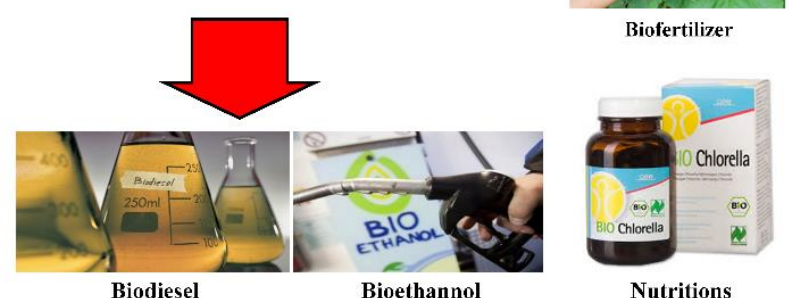

Nutritions

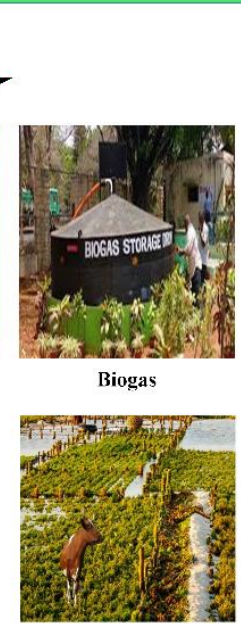

Animal Feed
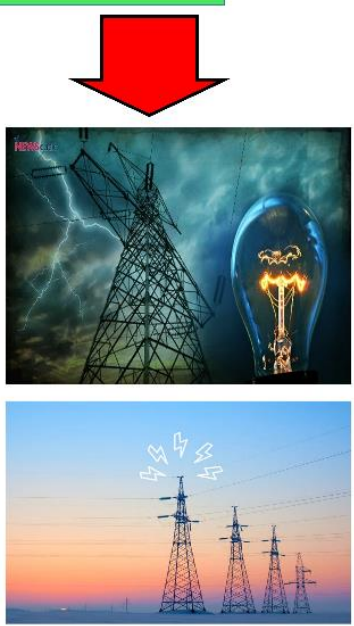

Electricity

Fig. 1. Schematic concept of converting microalgae to biofuels and value-added products 


\subsection{Algal biofuels and wastewater treatment}

Wastewater treatment is a growing issue worldwide, wastewater treatment through algae

3 was first studied in California, USA in 1950s. Algae were used as a tiny aerator to produce oxygen

4 for bacteria to consume and simultaneous degradation of organic matter wastewater. Bacteria

5 produce $\mathrm{CO}_{2}$ and other nutrients ( such as $\mathrm{N}$ and $\mathrm{P}$ ) which are highly needed for microalgae growth

6 during photosynthesis $[14,15]$. The symbiotic system efficiently removed nutrients from the

7 system. Initially, algal ponds were designed to treat the secondary effluent before discharging the

8 water to minimize the chances of eutrophication [16]. Algae could also remove the nutrients like

$9 \mathrm{~K}$ and $\mathrm{N}$ more efficiently in sewage than conventional treatment methods. Sewage process shows

10 great potential for algal cultivation, wastewater treatment and biofuel production [17].

11 Aquatic Species Programs in 1978 demonstrated that the concept of algae growth in

12 wastewater for biodiesel production is cost-effective as compared to petroleum-based diesel in the

13 closed report supported by the United State Department of Energy [18]. This report clearly

14 indicates that production of algal-biofuel is economically feasible when wastewater treatment is

15 combined with cultivation. Not only photoautotrophic growth showed high biomass growth rate,

16 but also heterotrophic microalgae utilize organic wastewater to increase the growth rate as well as

17 it gives higher biomass and lipid productivity [19-24]. Wastewater contains both organic and

18 inorganic sources of carbon which facilitate the conversion of microalgae through mixotrophic and

19 heterotrophic mode. These techniques for growing microalgae have many advantages over

20 photoautotrophic mode such as higher growth and productivity rate [24], low light [25] and 21 contamination rate [23].

22 Mixotrophic growth systems are also considered to be efficient in uptake of ammonium 23 and nitrogen enzymes. For example, in Scenedesmus obliquus (green algae) autotrophic medium 
1 acetate is added and cultivation occurs under mixotrophic condition. As a result, ammonium

2 uptake is increased four times than autotrophic conditions. In addition, harvesting cost is also

3 decreased due to the presence of higher density biomass especially in organic-rich wastewater with

4 the additional benefit of low downstream processing cost [22, 23]. Algal biomass production in

5 organic-rich wastewater (municipal) is widely studied and reported in the literature [25-27].

6 Additionally, many strategies have been developed for algal biomass conversion into value-added

7 products. For example, a study proposed a photoautotrophic-mixotrophic two-phase culture

8 (PMM) model in which organic materials (such as sucrose and glucose) are used as carbon-source

9 for algal-based biodiesel production [28]. A similar model, photoautotrophic-heterotrophic

10 (PHM) culture mode is designed to increase algal cell density production [29]. Recently, a new

11 model hetero-photo-autotrophic (HPM) culture mode was developed which shows increase

12 removal of nutrient and low production of biofuels in concentrated municipal wastewater, leading

13 to next step in algae cultivation systems [30]. Different microalgae species and their productivity

14 are shown in Table1.

15 Table 1 Comparison of microalgae species and their lipids productivity

\begin{tabular}{llll}
\hline Microalgae species & Alga type & Productivity of lipids (mg/L/day) & Reference \\
\hline Chaetoceros muelleri & Diatom & 21.8 \\
Chlorella sorokiniana & Green & 44.7 \\
Chlorococcum sp. UMACC 112 & Green & 53.7 \\
Chlorella vulgaris CCAP 211/11b & Green & 170 \\
Ellipsoidion sp. & Eustigmatophytes & 47.3 \\
Monodus subterraneus UTEX 151 & Eustigmatophytes & 30.4 \\
Pavlova salina & Prymnesiophytes & 49.4 \\
Pavlova lutheri & Prymnesiophytes & 40.2 \\
Scenedesmus quadricauda & Green & 35.1 \\
Scenedesmus sp. DM & Green & $40.8-53.9$ \\
Skeletonema sp. & Diatoms & 27.3 \\
Skeletonema costatum & Diatoms & 17.4 \\
\hline
\end{tabular}




\begin{tabular}{llll}
\hline Thalassiosira pseudonana & Diatoms & 17.4 & \\
Tetraselmis sp. & Green & 43.4 & [32] \\
Chlorella sp. & Green & 18.7 & {$[33]$} \\
Dunaliella salina & Green & 46 & \\
Isochrysis sp. & Prymnesiophytes & 37.8 & [34-37] \\
Nannochloropsis sp. & Eustigmatophytes & $37.6-90$ & \\
Tetraselmis suecica & Green & $27-36.4$ & [37] \\
Nannochloris sp. & Green & $60.9-76.5$ & \\
Nannochloropsis oculata. & Green & $84-142$ & [36] \\
Phaeodactylum tricornutum & Diatoms & 44.8 & [38] \\
Nannochloropsis oculata NCTU-3 & Green & 142 & \\
Porphyridium cruentum & Red & 34.8 & \\
\hline
\end{tabular}

2 Cultivation of microalgae

3 Microalgae are prokaryotic photosynthetic microorganisms. In a natural environment, they

4 fix atmospheric $\mathrm{CO}_{2}$, use organic carbon from the wastewater, and light from the sun. To cultivate

5 microalgae in an artificial environment, the resource input should well match with the natural

6 environment [39]. The most important factor of hindering in commercialized production of algae

7 is the limited access of sunlight. To minimize this factor, an artificial source of light is implemented

8 for the cultivation of microalgae such as fluorescent light. But artificial light source derived from

9 petroleum energy diminishes major aim of producing a cost-effective method and it also increases

10 the carbon footprint [40].

11 There are three different sources for $\mathrm{CO}_{2}$ uptake for microalgae growth- (i) $\mathrm{CO}_{2}$ as

12 discharge gas from industry, (ii) from atmosphere and (iii) from carbonates [41]. Recent reports

13 revealed that air contains $400 \mathrm{ppm}$ of $\mathrm{CO}_{2}$ [42], but most microalgae utilize higher $\mathrm{CO}_{2}$ levels [36].

14 Therefore, microalgae production uses some external sources of $\mathrm{CO}_{2}$ such as industrial discharge

15 or soluble carbonates at commercial-scale [42]. Fig. 2 shown conventional routes of microalgae 16 cultivation. 


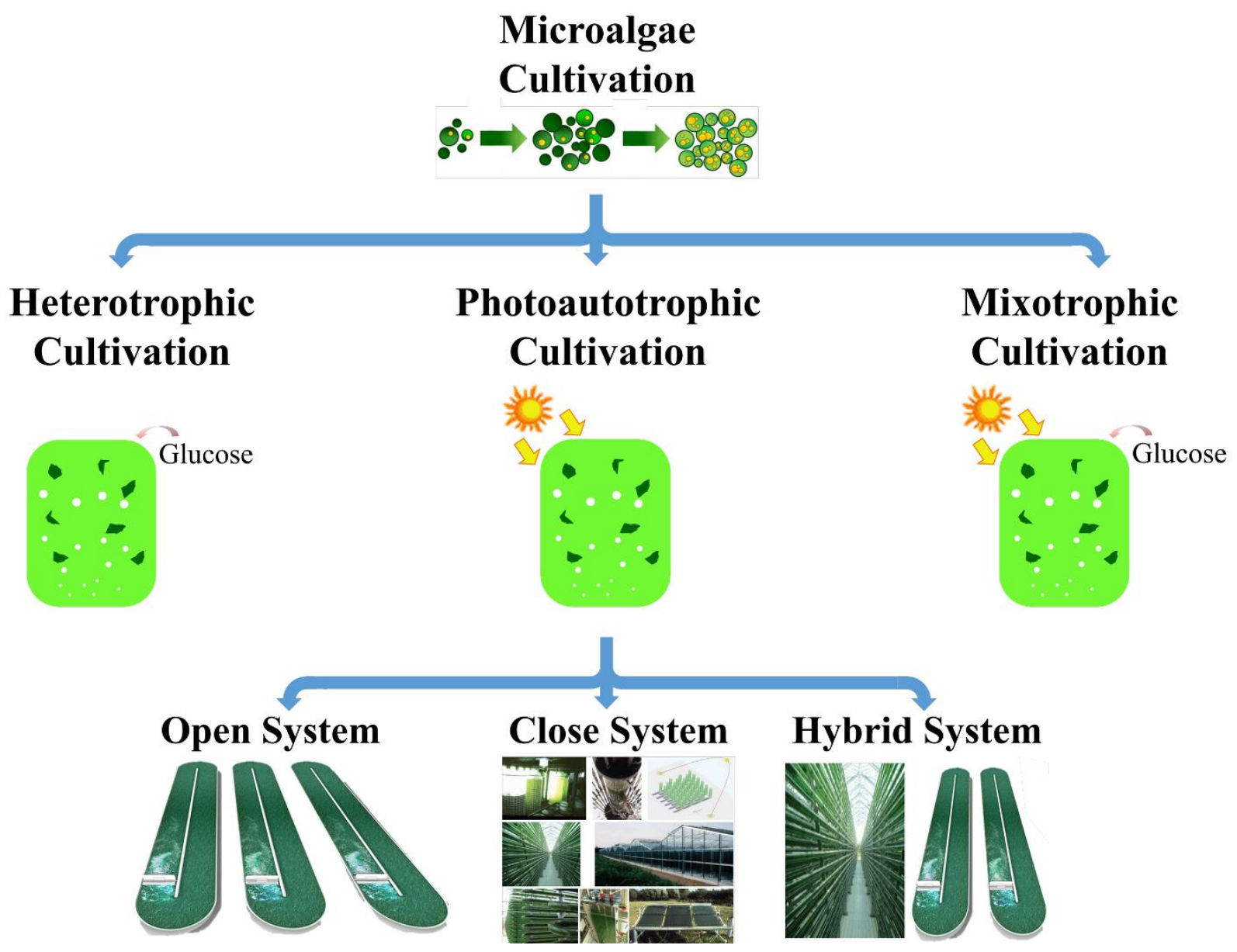

Fig 2. Microalgae cultivation system

\section{$3 \quad 2.1 \quad$ Photoautotrophic cultivation}

4 Phototrophic cultivation is the cheapest mode of microalgae cultivation. Phototrophic

5 cultivation can be carried out in open ponds as well as closed bioreactors at lab scale [43]. Open

6 pond systems are more beneficial because these are cheaper than photobioreactors, but the limited

7 number of microalgae species are cultivated in open pond.

\section{2.1.1 Photoautotrophic open cultivation system}

10 type which was proposed by Oswald 1969. The most common design of raceway ponds often 
1 consists of the rectangular channel with the flow from one end to another [44]. For raceway pond

2 length, depth and diameter/width is an important parameter. Increase in pond width may results in

3 current speed decrease leading to a lower mass transfer and mixing. Depth and length are

4 dependent on the amount of culture volume used and light penetration. Open cultivation systems

5 have been demonstrated cost-effective and sustainable mode of cultivation. They require less

6 energy, easy to maintain and clean and, consequently, have the potential to return high net

7 production of energy. However, water loss, lower light utilization, and large required space are the

8 major limitations of open pond systems. Moreover, limited type of algae production, impure

9 culture growth, insufficient mixing and low biomass productivity are the constraints of the

10 technology [44].

\section{2.1.2 Photoautotrophic closed cultivation system}

Photobioreactors are mostly closed containers used for the production of phototrophic

13 microalgae, where energy is provided through the artificial source of light [45]. They offer uniform

14 distribution and efficient utilization of light distribution resulting in high mass transfer of gases

15 (like $\mathrm{CO}_{2}$ and $\mathrm{O}_{2}$ ). Typically, closed systems consist of four phases: solid, liquid, gas, and light

16 phase. Microalgae as solid phase, growth media liquid phase, $\mathrm{CO}_{2}$ and $\mathrm{O}_{2}$ are a gaseous phase, and

17 light phase [46]. Closed systems include tubular [47], flat plate [48, 49], and column

18 photobioreactors [50]. An ideal closed system would have high transparent surface and high

19 minimum illuminated parts. Closed systems are considered best for cultivation of a specific species

20 in a controlled environment.

21 Flat-plate reactors were used as closed systems [51]. They have high surface area and high

22 densities of microalgae cells, greater than $80 \mathrm{~g} / \mathrm{L}$ [52]. They are made up from a transparent

23 material and have a high capture rate of solar energy and these reactors have high photosynthesis 
1 efficiency as compared to tubular bioreactor [53, 54]. Scaling up of tubular reactor is troublesome.

2 Large tubular reactor can only be manufactured by joining smaller units presenting an operation

3 and maintenance problems. However, significantly tubular reactor are working worldwide such as

$425 \mathrm{~m}^{3}$ at Mera Pharmaceuticals Hawaii [55], and even larger at Klotze, Germany having a volume

5 of $700 \mathrm{~m}^{3}$ [56]. To overcome these problems, Column bioreactors were proposed. They have a

6 high volumetric mass transfer, controllable growth conditions, compact design and easy to operate 7 [50].

$8 \quad$ 2.1.2.1 Membranes photobioreactors

9 The biomass productivity of microalgae cultivation system largely depends on $\mathrm{CO}_{2}$ 10 delivery. Generally, $\mathrm{CO}_{2}$ delivery is carried out by simple air bubbling. Mixing is insufficient 11 causing poor mass transfer and low efficiency. This problem can be addressed by using membrane 12 aided bioreactors offering higher mass transfer of $\mathrm{CO}_{2}$ than conventional bioreactors.

$13 \mathrm{CO} 2$ sequestration using a membrane photobioreactors is as shown in Fig. 3 [57]. This

14 process is carried out in two steps: (1) membrane is used to remove water continuously while

15 biomass is retained on the membrane and (2) during cultivation, membrane is used to provide $\mathrm{CO}_{2}$

16 either as contacted or as sparger. Over time many membrane systems have been studied for 17 microalgae cultivation.

18 Hollow fiber membrane photobioreactors are adopted for microalgae cultivation due to 19 their increased interfacial area and high algal biomass for biofuel conversion from wastewater with 20 high nutrients strength. Highest biomass productivity of $4 \mathrm{~g} / \mathrm{m}^{3} / \mathrm{h}$ was reported for Chlorella

21 vulgaris. The analysis shows that a combination of wastewater treatment, $\mathrm{CO}_{2}$ sequestration, and

22 biofuels production is a promising route for microalgae cultivation [58]. Different applications for 
2 their biomass productivity as shown in Table 3.

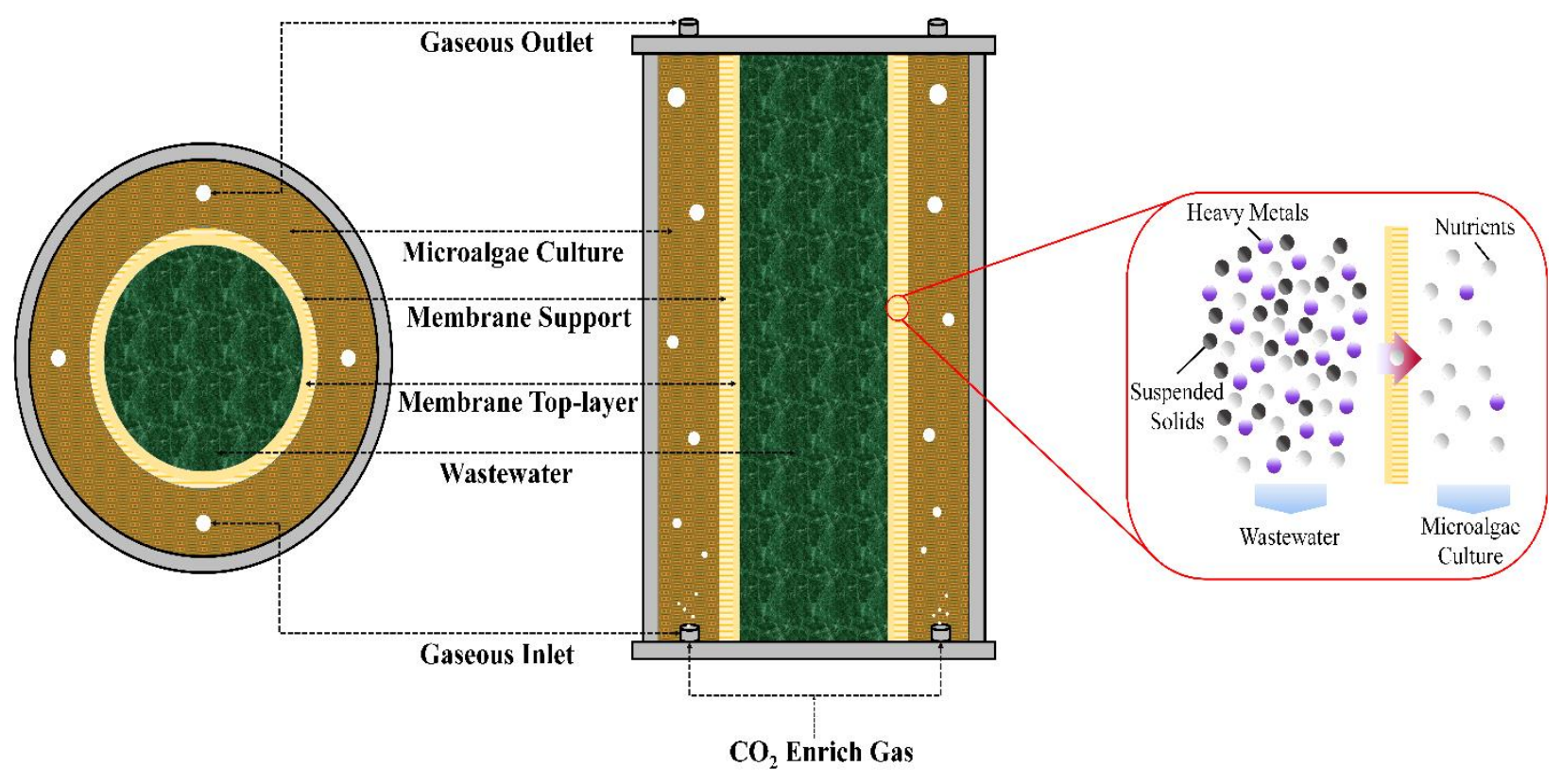

4 Fig. 3. Membrane photobioreactor for wastewater treatment and microalgae cultivation. Reproduced from 5 Ref. [57]. Copyright 2016 Elsevier.

6 Table 2 Summary of membrane photobioreactors for microalgae cultivation

\begin{tabular}{|l|l|l|l|l|}
\hline Membrane & Microalgae & objective & Parameters & Reference \\
\hline $\begin{array}{l}\text { Polyvinyledene } \\
\text { fluoride hollow } \\
\text { fiber }\end{array}$ & Chlorella vulgaris & $\begin{array}{l}\mathrm{CO}_{2} \text { capture and } \\
\text { removal of } \\
\text { nutrients }\end{array}$ & Poration: $0.156 \mathrm{~L} / \mathrm{min}$ & {$[59]$} \\
\hline $\begin{array}{l}\text { Hydrophilic poly } 0.1 \mu \mathrm{m} \\
\text { (ether sulfones) } \\
\text { hollow fiber }\end{array}$ & $\begin{array}{l}\text { Scenedesmus } \\
\text { Quadricauda }\end{array}$ & $\begin{array}{l}\text { Removal of } \\
\text { nutrients }\end{array}$ & Aeration rate: $4 \mathrm{~L} / \mathrm{min} / \mathrm{m}^{2} / \mathrm{h}$ & {$[60]$} \\
\hline
\end{tabular}




\begin{tabular}{|l|l|l|l|l|}
\hline $\begin{array}{l}\text { Hydrophilic } \\
\text { polyvinyl chloride } \\
\text { (PVC) / silica }\end{array}$ & Chlorella vulgaris & $\begin{array}{l}\text { Coupled } \\
\text { cultivation and } \\
\text { harvesting of } \\
\text { Chlorella vulgaris }\end{array}$ & Flux: $1.5-8.63 \mathrm{~L} / \mathrm{m}^{2} / \mathrm{h}$ & Aeration rate: $2 \mathrm{~L} / \mathrm{min}$ \\
\hline $\begin{array}{l}\text { Polyacrylonitrile } \\
\text { ultra-filtration flat } \\
\text { sheet }\end{array}$ & Haslea ostrearia & $\begin{array}{l}\text { Pocellular } \\
\text { metabolite } \\
\text { (marennine } \\
\text { pigment) }\end{array}$ & Flux: $3-10 \mathrm{~L} / \mathrm{m}^{2} / \mathrm{h}$ & [61] \\
\hline $\begin{array}{l}\text { Chlorinated } \\
\text { polyethylene }\end{array}$ & $\begin{array}{l}\text { Chlorella } \\
\text { vulgaris }\end{array}$ & $\begin{array}{l}\text { MBBR for an MBR } \\
\text { effluent polishing }\end{array}$ & Pore size: $0.2 \mu \mathrm{m}$ & [63] \\
\hline
\end{tabular}

2 Table 3 Photobioreactors and their biomass productivity

\begin{tabular}{llll}
\hline Photobioreactors & Microalgae species & Productivity of biomass (g/L/day) & Reference \\
\hline Tubular system & Porphyridium cruentum & 1.5 & {$[64]$} \\
Tubular system & Phaeodactylum tricornutum & 1.2 & {$[65]$} \\
Tubular system & Phaeodactylum tricornutum & 1.9 & {$[47]$} \\
Inclined tubular system & Chlorella sorokiniana & 1.47 & {$[66]$} \\
Undular row tubular system & Arthrospira platensis & 2.7 & {$[67]$} \\
helical tubular system & Phaeodactylum tricornutum & 1.4 & {$[68]$} \\
Parallel tubular system & Haematococcus pluvialis & 0.05 & {$[55]$} \\
Bubble column & Haematococcus Pluvialis & 0.06 & {$[69]$} \\
Tubular system & Haematococcus Pluvialis & 0.41 & {$[70]$} \\
Tubular system & Spirulina platensis & 0.42 & \\
\hline
\end{tabular}




\begin{tabular}{llll}
\hline Flat plate system & Nannochloropsis sp. & 0.27 & [71] \\
Flat plate system & Chlorella & 3.8 & {$[72]$} \\
Column system & Tetraselmis & 0.42 & {$[73]$} \\
Parabola system & Chlorococcum & 0.09 & {$[74]$} \\
Dome system & Chlorococcum & 0.1 & \\
Membrane system & Chlorella vulgaris & 0.08 & {$[58]$} \\
\hline
\end{tabular}

\section{2.1.3 Photoautotrophic hybrid cultivation system}

Hybrid cultivation consists of two-step microalgae growth in photobioreactor and in open

4 ponds. In the first step, photobioreactors are used in which controlled conditions are provided to

5 minimize the chances of contaminations and favored cell division. In second step, cells are exposed

6 to the nutrients, which help to increase lipid productivity [31]. The second step is preferably an

7 open pond, where environmental effects help in the production of microalgae. Huntley and Redalje

8 [75] studied hybrid system for oil and astaxanthin production by using Haematococcus pluvialis

9 and achieved oil production rate 10 tons of oil /ha. They also showed that oil production rate can

10 be achieved 76 tons of oil/ha/year by using high oil content species.

11 Rodolfi et al. [31] gave the concept of two-stage oil production, in which one part of plant

12 is dedicated for biomass under nitrogen sufficiency and rest of the plant is assigned for oil

13 production under nitrogen deprivation. Due to this process, $10 \mathrm{~kg}$ of lipid/ha/day produced in the

14 first section of the plant and $80 \mathrm{~kg}$ of lipid /ha/day produced in the second section and overall

15 production rate is $90 \mathrm{~kg}$ of lipid/ha/day. For tropical areas of the world where average solar 16 radiation is $20 \mathrm{MJ} / \mathrm{M}^{2} /$ day can produce almost 30 tons of oil/year. 


\section{$1 \quad 2.2$ Heterotrophic cultivation}

2 Algal biomass can successfully be produced by heterotrophic production as shown in Table

$34[76,77]$. In this process algae grows on carbon substrate such as glucose in fermenters. In

4 heterotrophic production, algae growth is independent of light energy making the process simpler

5 and easy to scale-up [50, 78]. These processes have a higher growth rate and also lowering the

6 harvesting costs due to high cell densities [79]. The installation cost is lower. However, this process

7 consumes more energy than photosynthesis as it requires an organic source for initiation of the

8 process [44]. Many other studies suggested a higher production rate in heterotrophic as compared

9 with photoautotrophic [80-82]. Miao and $\mathrm{Wu}$ [77] studied that heterotrophic cell could be almost

104 times greater than autotrophic cells in similar conditions. Hence, the cultivation through

11 heterotrophic can result in higher lipid and biomass content.

12 Table 4 Heterotrophic microalgae species and their lipid content

\begin{tabular}{lllll}
\hline Species & Product & Culture & $\begin{array}{l}\text { Total lipid } \\
\text { content (\%) }\end{array}$ & Reference \\
\hline Chlorella protothecoides & Biodiesel & Batch & 57.8 & [82] \\
Chlorella protothecoides & Biodiesel & Batch & 55.2 & \\
Chlorella protothecoides & Biodiesel & Batch & 50.3 & [80] \\
Crypthecodinim cohnii & Docosahexaenoic acid & Batch & 56 & [81] \\
Crypthecodinim cohnii & Docosahexaenoic acid & Batch & 42 \\
Chlorella protothecoides & Biodiesel & Batch & 46.1 \\
Chlorella protothecoides & Biodiesel & Batch & 48.7 \\
Chlorella protothecoides & Biodiesel & Batch & 44.3 \\
\hline
\end{tabular}




\section{$1 \quad 2.3$ Mixotrophic cultivation}

2 Some microalgae species use metabolism for growth (heterotrophic or photoautotrophic),

3 with the ability to grow on photosynthesis as well as ingest pray from organic material [83] as

4 shown in Table 5. These species can rely on both photosynthesis and organic substrates such as

5 cyanobacteria spirulina platensis [76]. The growth of microalgae is highly influenced by media

6 during dark and light phase, due to which biomass losses were minimal during dark phase [84].

7 To get maximum biomass formation from mixotrophic cultures, integration of both photo and

8 heterotrophic processes during cultivation can be investigated. These factors indicate that

9 mixotrophic production can play a significant role for microalgae to biofuel production.

10 Table 5 Mixotrophic species and biomass concentrations

\begin{tabular}{llll}
\hline Species & Organic carbon source & $\begin{array}{l}\text { Biomass Concentration } \\
(\mathrm{g} / \mathrm{L})\end{array}$ & Reference \\
\hline Spirulina platensis & Glucose & 2.66 & {$[76]$} \\
Spirulina platensis & Acetate & 1.81 & {$[76]$} \\
Spirulina sp. & Glucose & 2.50 & {$[85]$} \\
Spirulina platensis & Molasses & 2.94 & {$[84]$} \\
\hline
\end{tabular}

\section{Microalgae Harvesting}

13 Harvesting microalgae economically, due to its smaller size $(3-30 \mu \mathrm{m})$, is a barrier yet to

14 overcome [86]. Harvesting complicate downstream processing inflicting process economic s

15 adversely. Currently, harvesting is carried out by chemical based, mechanical based, biological

16 based and to some extent electrical methods as shown in Fig 4. All these methods have been

17 investigated intensively to reduce the harvesting cost. However, no single method has provided an 18 economical solution. [87]. 


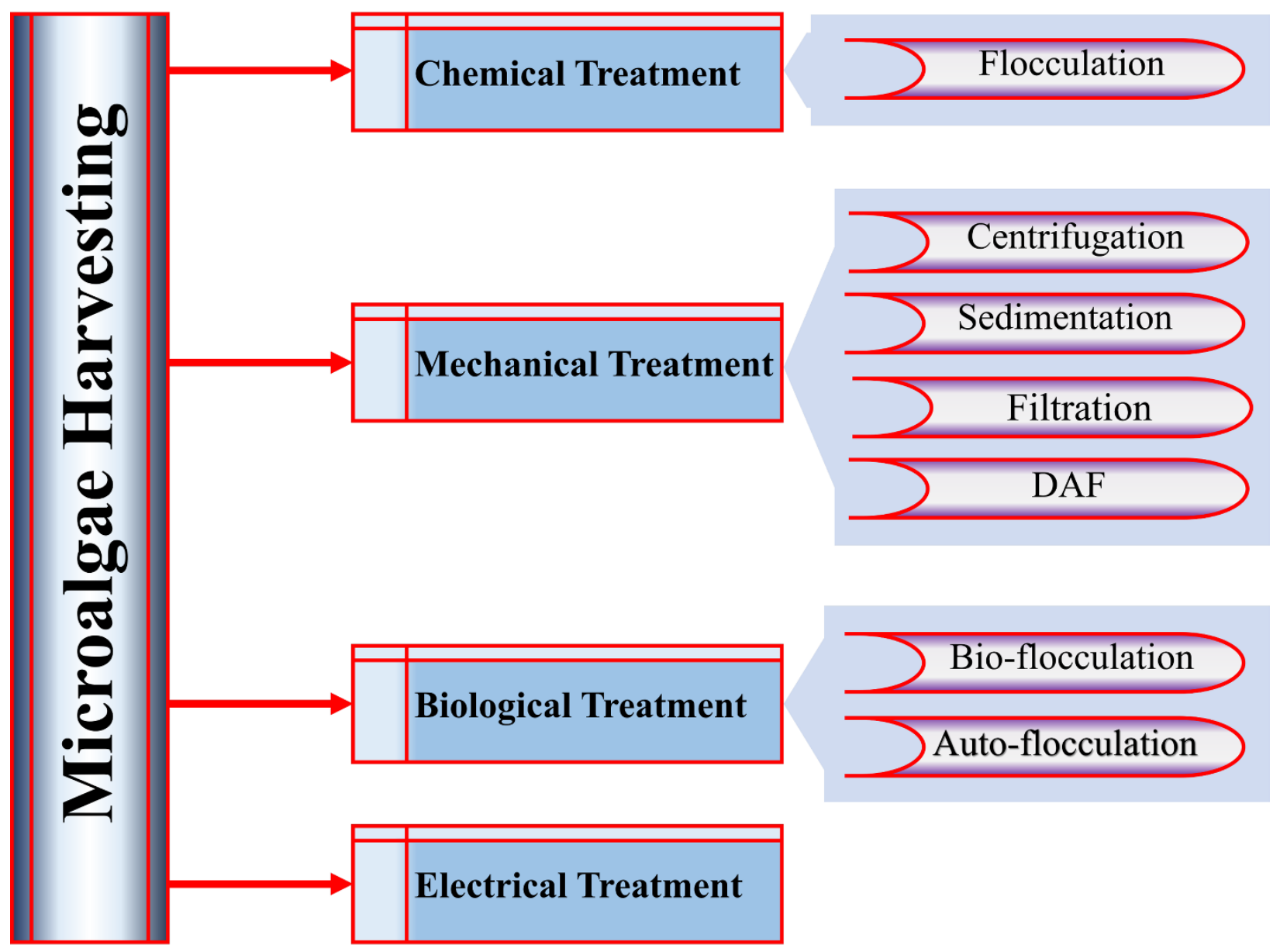

Fig 4 Techniques for microalgae harvesting

\section{$3 \quad 3.1 \quad$ Chemical treatments}

$4 \quad$ Owing to smaller cellular size, microalgae tend to remain suspended in aqueous solution

5 and difficult to remove from the medium due to stable suspension. The addition of chemical

6 flocculants can help to destabilize the cells and agglomerate them to settle down through

7 gravitational forces. Synthetic polymers and electrolytes are used to neutralize the charge and

8 flocculate the cells [88]. Ferric chloride and aluminum sulfate are used for neutralization of charge

9 due to presences of +3 charges on their cations. The use of metal salts in flocculation and

10 coagulation is not recommended considering the downstream processing for the bio-based 
1 products formed by algae because aluminum and sulfate shows the methanogenic activity. For

2 land applications, aluminum treated sludge have increased uptake and causes phosphorous

3 deficiencies in plants. To minimize the concern of secondary pollution, natural polymers are used

4 as flocculants. The use of natural polymer is not extensively reported. Divakaran and Pillai [89]

5 worked on flocculation and settling of algae by adding chitosan sheds some light on the application

6 of natural polymers. Starch is also used in freshwater as an efficient flocculating agent for the lab-

7 scale experiment.

\section{$8 \quad 3.2 \quad$ Mechanical treatments}

9 Centrifugation is one of the most efficient method for microalgae recovery. In this process

10 centrifugal force accelerates the separation of particles on the basis of their density difference [90].

11 Most of the microalgae gave 80 to $90 \%$ recovery within 2 to $5 \mathrm{~min}$ for a pond effluent of 500 to

12 1000xg. Centrifugation offers high recovery, but it's an energy-intensive process. This method is

13 preferred for algal cell recovering, especially for concentrated aquaculture The factor affecting

14 biomass recovery are: cell settling characteristics, settling depth and residence time [91].

15 According to Shelef et al. [95], disc centrifuges can be used for all types of microalgae; also they

16 can easily be sterilized and cleaned but high principal investment and operational costs limits the

17 application of mechanical treatment to industrial use only.

18 Sedimentation process is mostly used for separating microalgae from water in which

19 separation depends on microalgae particle size and density [90]. This process is recommended for

20 microalgae size greater than $70 \mu \mathrm{m}$. This process requires a low capital investment and recover

$211.5 \%$ concentration of biomass [92]. However, the reliability of this process is also very low due

22 to the dilute densities of algal cells. Sedimentation process is slow, for example, 0.1 to $2.6 \mathrm{~cm} / \mathrm{h}$

23 with biomass losses during settling time as well [93]. 
Dissolved air flotation (DAF) is used for sludge removal from wastewater treatment [94].

2 This method is preferred over sedimentation in algae-rich water containing 3-6\% algal biomass.

3 The main advantage of DAF is that it can be employed at a large scale. However downstream

4 processing becomes difficult due to addition of flocculants [93]. Recently, Hanotu et al. [95]

5 reported microbubble harvesting known as microflotation using oscillatory flow through fluidic

6 oscillator (FO). Using FO, the size of the bubbles generated were reported to be 10 times smaller

7 than produced by DAF. Microflotation recovered $99 \%$ algae in $30 \mathrm{~min}$. Oscillatory flow has been

8 used for mass transfer enhancement for several other applications as well [95, 96] [97].

9 Harvesting of microalgae is still facing challenges due to its smaller size, similar densities

10 to water, and recovery of biomass costing 20 to $30 \%$ of the total cost of biomass production.

11 Membrane technology is known for low energy-intensive process compared to other technologies,

12 due to their isothermal behavior and no phase change. Moreover, membranes provide complete

13 retention of biomass and additional chemicals such as coagulants or flocculants are not required.

14 It also helps removal of viruses and protozoa from liquid effluents [98-100]. For smaller algal

15 cells, membrane filtration is more appropriate as compared to simple filtration. Membrane

16 technology for harvesting purposes was first reported in 1995. Petrusevski et al. [101] studied the

17 potential of a tangential flow filtration system. The result indicated that almost 70 to $80 \%$ of

18 biomass was recovered. It is an efficient method of microalgae harvesting. However, membrane

19 fouling is a major issue in commercialization of this technology [102-104]. Overcoming membrane

20 fouling is energy intensive and frequent chemical cleaning is required which results in reduced

21 membrane lifetime and increased operating cost [105-112].

22 Different membrane materials have been tried for microalgae harvesting. However, a 23 specific criterion for selection of membrane material for microalgae harvesting has not been 
1 developed so far. Rossi et al. [101] have studied different materials for microalgae membrane

2 filtration. They studied 11 commercial polymers for harvesting microalgae by using cross-flow

3 microfiltration and ultrafiltration. Hydrophilic membrane showed more efficient results than other

4 membranes. These membranes are easy to clean, due to the negatively charged membrane fouling

5 and cake formations [10, 101, 113-116]. Different mechanical harvesting methods and their

6 comparison are shown in Table 6.

7 Table 6 Different mechanical harvesting methods and their comparison [92, 93, 117, 118]

\begin{tabular}{|c|c|c|c|c|c|c|}
\hline Method & $\begin{array}{l}\text { Concentration } \\
\text { after harvesting } \\
(\%)\end{array}$ & $\begin{array}{l}\text { Recovery } \\
(\%)\end{array}$ & Energy Usage & Merits & & Demerits \\
\hline Centrifugation & $12-22$ & $>90$ & $\begin{array}{ll}- & \text { Energy } \\
& \text { Intensive }\end{array}$ & - & $\begin{array}{l}\text { Reliable } \\
\text { Solid } \\
\text { concentration } \\
\text { is high }\end{array}$ & 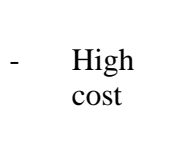 \\
\hline $\begin{array}{l}\text { Membrane } \\
\text { Filtration }\end{array}$ & $5-22$ & $70-90$ & - $\quad 0.4 \mathrm{kWh} / \mathrm{m}^{3}$ & & $\begin{array}{l}\text { Reliable } \\
\text { Solid } \\
\text { concentration } \\
\text { is high }\end{array}$ & $\begin{array}{ll}- & \text { Fouling } \\
- & \text { High } \\
\text { cost }\end{array}$ \\
\hline Sedimentation & $0.5-3$ & $10-90$ & $\begin{array}{ll}- & \text { Very high } 8 \\
\mathrm{kWh} / \mathrm{m}^{3}\end{array}$ & - & Cheap & $\begin{array}{ll}\text { - } & \text { Time } \\
\text { consumi } \\
\text { ng } \\
\text { process } \\
\text { - } \quad \text { Unrelia } \\
\text { ble }\end{array}$ \\
\hline $\begin{array}{l}\text { Dissolved air } \\
\text { flotation }\end{array}$ & $3-6$ & $50-90$ & $\begin{array}{ll}\text { - } & \text { High } \\
\text { dissolved air } \\
\text { - } \\
\text { flotation } 10- \\
20 \mathrm{kWh} / \mathrm{m}^{3}\end{array}$ & - & $\begin{array}{l}\text { Large scale } \\
\text { process }\end{array}$ & 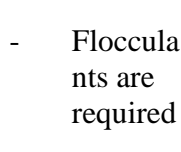 \\
\hline
\end{tabular}

8

$9 \quad 3.3 \quad$ Electrical treatments

10 For electrical treatment, electrophoresis method is used for harvesting algae cells. Due to

11 the negative charge of algae, they can be moved by applying electric field [87]. The only benefit 
1 of this process is no chemicals are used for harvesting of microalgae. But high power consumption

2 makes this process significantly cost intensive making it an unattractive option for harvesting at

3 large-scale production [92].

\section{$4 \quad 3.4 \quad$ Biological treatments}

5 The two basic terms used for biological harvesting of microalgae are auto-flocculation and

6 bio-flocculation. Auto-flocculation occurs at high $\mathrm{pH}$ and dissolved $\mathrm{CO}_{2}$ concentration. Due to

7 high $\mathrm{pH}$, supersaturation of calcium and phosphate ions occurs. Positive charge on calcium ions

8 attract the negative charge on algae faciltating the settling of microalgae [119]. The optimum $\mathrm{pH}$

9 for this process is 8.5 to 9 where 3.1 to $6.2 \mathrm{mg} / \mathrm{L}$ of phosphate and 60 to $100 \mathrm{mg} / \mathrm{L}$ calcium is

10 reported. This is very difficult to maintain, with the additional constraint of no possibility of auto-

11 flocculation in all types of water. This limitation is rectified by Oswald in 1995 by adding lime in

12 raceway pond. This method gives $90 \%$ removal of $\mathrm{N}, \mathrm{K}$, and algae. The bio-flocculation process

13 is carried out by flocculation using bio-polymers. Passow [120] reported controlled diatoms bloom

14 underwent mass flocculation increased by biopolymers. Extracellular polymeric substance (EPS)

15 produced by biofilms increased solid flocculation in clarifier operation [120].

\section{Conversion of biomass into value-added products}

\section{$17 \quad 4.1$ Biomass to biofuels}

18 Biofuels are sustainable energy sources that can replace fossil fuels. Biofuels are produced

19 from biomass such as residues, spent coffee grounds, wastewater, algae, and other biological

20 materials [121]. Biomass can be converted into different forms of energy such as heat, electricity,

21 and biogas, etc. [122]. The production of biofuel is categorized into three generations according to

22 their feedstock [123]. In the $1^{\text {st }}$ generation, the feedstock is food crops such as sugarcane, soybeans, 
1 and corns, etc. This feedstock raises the conflict between food versus fuel and also increases the

2 price of feedstock which adversely affects the world food market [5, 124, 125]. Also, the biofuels

3 produced from first generation feedstock such as soybean biodiesel are not compatible in term of

4 energy yield per acre [5]. The $2^{\text {nd }}$ generation biofuels tackled the first-generation problems as they

5 are produced from non-edible feedstock such as Jatropha and Pongamia. However, cultivation of

6 energy crops for biofuel production requires vast land. Consequently, energy required for

7 harvesting and transport these corps is increased as well. Moreover, the biofuels generated from

8 the second generation has half of the energy content as compared with conventional fuels such as

9 coal $[124,126]$.

10 In $3^{\text {rd }}$ generation, algae are used to produce biofuels. It is a viable alternate energy source 11 as it tackles all the major issue with $1^{\text {st }}$ and $2^{\text {nd }}$ generation biofuels. Microalgae have high 12 photosynthetic efficiency. Moreover, it has high oil yield productivity compared to other oil crops 13 [127]. Microalgae use solar energy to produce oils and convert it into biofuel and can produce 200 14 to 5000 gallons of biofuel per acre per year [5]. Comparison of all three generations is given in 15 Table 7.

16 
Table 7 Comparison of all three generation biofuels

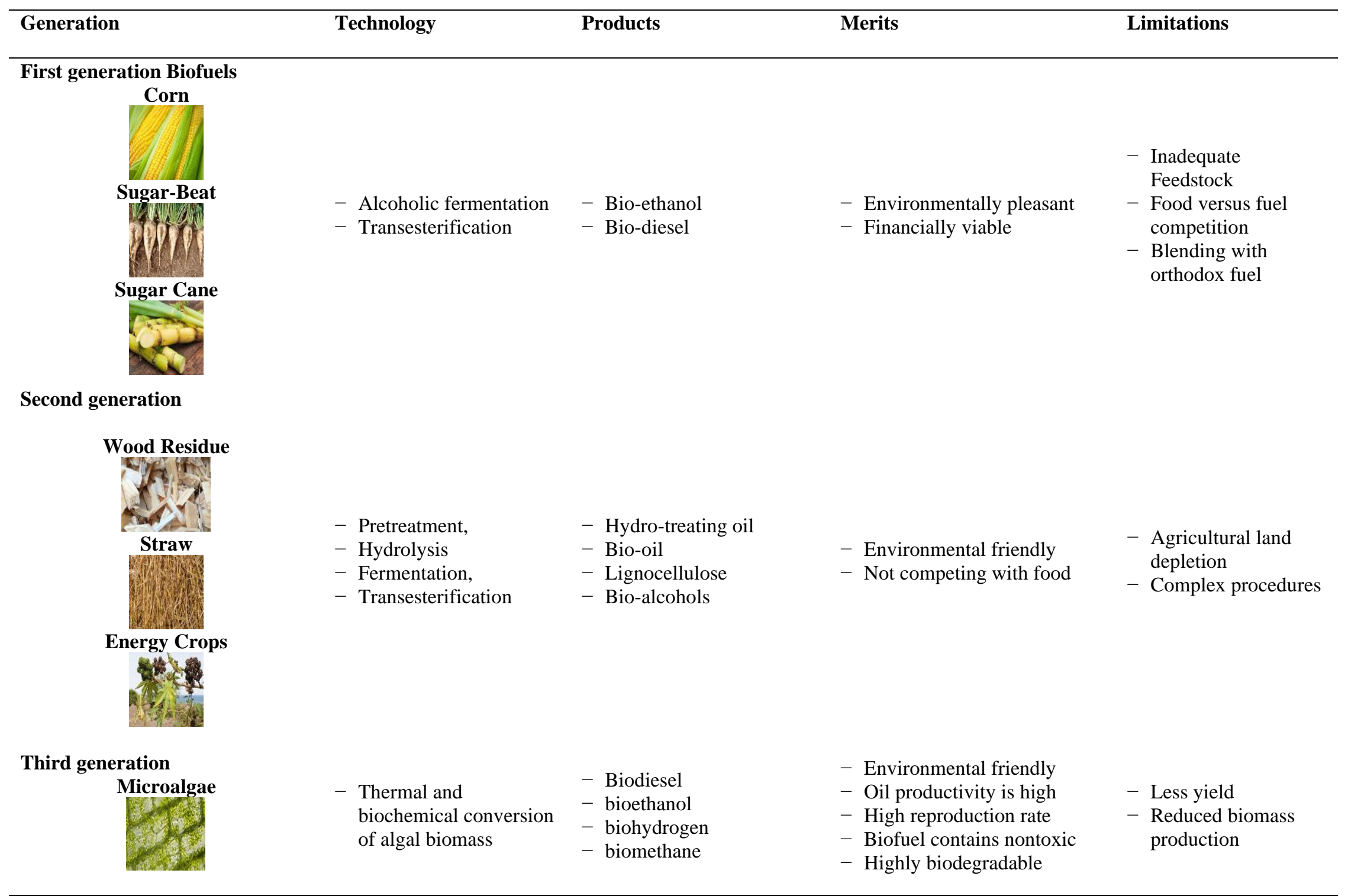




\subsubsection{Algal biomass conversion technologies}

Algal biomass conversion into energy encompasses different processes, entirely dependent

3 on types of biomass, conversion options, and its end use. Microalgal biomass conversion is

4 categorized in two types-(i) thermo and (ii) biochemical conversion [128-130] as shown in Fig. 5.

5 Influencing factors for conversion of biomass are quality of biomass, feedstock, and desire energy

6 content [124].

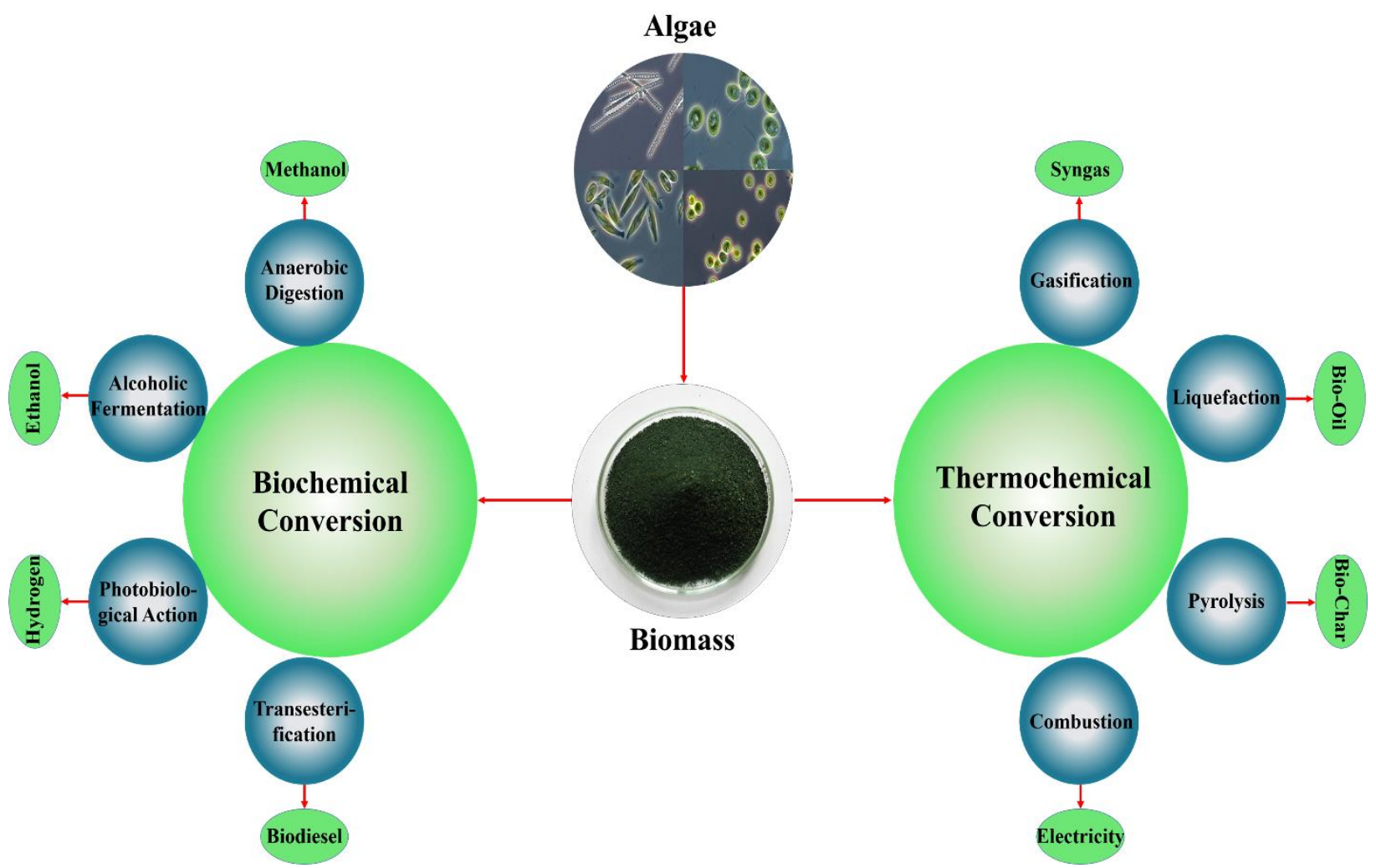

Fig. 5. Microalgae conversion technologies for the production of biofuels

\subsubsection{Thermochemical conversion}

In this process, biomass is thermally decomposed to produce fuel products. The technique

11 includes combustion, gasification, liquefaction, and pyrolysis [131]. Comparison of all thermal

12 technologies is shown in Table 8. 


\section{$1 \quad$ 4.1.1.1.1 Gasification}

2 In this process, hydrocarbons are converted under limited supply of oxygen to produce 3 combustible gaseous mixture (syngas) [132]. It can burn directly or use as a fuel for gas engines.

4 However, it has a low calorific value of 4-6 MJ/m³ . There are two different routes for transporting 5 fuels through syngas: (1) hydrogen production by water gas shift reaction; and (2) Fischer Tropsch

6 conversion of hydrocarbons to produce liquid fuels/chemicals such as methanol [133, 134].

7 Several studies have been reported for converting microalgae biomass into biofuel through 8 gasification. Hirano et al. [135] studied Spirulina partially oxidized at high temperature at 850 to

$9 \quad 1000{ }^{\circ} \mathrm{C}$ to determine the gas composition required to generate methanol. Highest theoretical yield $10 \quad 0.64 \mathrm{~g}$ of methanol for $1 \mathrm{~g}$ of biomass was obtained at $1000{ }^{\circ} \mathrm{C}$. They estimated energy balance 11 that showed marginal positive balance. [135].

\section{4.1.1.1.2 Liquefaction}

13 In this process, wet-algal biomass is used to produce liquid fuel. Microalgae cells derived 14 from mechanical harvesting have high moisture and are used as raw material for liquefaction [129, 15 136]. Generally, this process produces oils of high viscosity and requires biomass, solvents, and 16 gases like $\mathrm{H}_{2}$ or $\mathrm{CO}$ as well as catalysts. Liquefaction can consume wet biomass and converts it 17 into the smaller molecular material with higher energy densities [132, 137-139]. Dote et al. [34] 18 reported liquefaction of B. braunii, with $64 \%$ yield (dry weight) at $300{ }^{\circ} \mathrm{C}$. Dunaliella tertiolecta 19 gave oil yield of $42 \%$ dry weight. This clearly reveals that liquefaction is also a vital option for 20 biomass conversion [34].

\section{$21 \quad$ 4.1.1.1.3 Pyrolysis}

Algal-biomass can be used to produce various products such as biochar, bio-oil, and syngas

23 in the absence of air at 350 to $700{ }^{\circ} \mathrm{C}$ [140]. Pyrolysis can convert biomass to liquid fuels and can 
1 be up-scaled for large-scale production. Flash pyrolysis, occurring at $500{ }^{\circ} \mathrm{C}$, is one of the most

2 important techniques for future petroleum replacement with liquid biofuels. As it can achieve high

3 biomass to liquid ratio of almost $95.5 \%$ [141]. However, commercialization of the microalgal

4 pyrolysis still requires to address some major challenges. Oil generated in this process is acidic in

5 nature, highly viscous, has solid and water in it. The process also requires further development in

6 hydrogenation and catalytic cracking to remove alkali and lower the oxygen content [132].

7 The conventional process is divided into three stages. In first stage, decomposition of

8 biomass at 550-950 $\mathrm{K}$ is known as pre-pyrolysis. In this step, water is removed following by bond

9 breakage and then carbonyl and carboxyl groups are formed. In second stage, pyrolysis products

10 are formed as a result of solid decomposition. In third stage, char decomposes to carbon-rich

11 residues. Fast pyrolysis process occurs at 850 to $1250 \mathrm{~K}$, as a result, biomass decomposes and

12 pyrolysis products are formed. The product's composition is bio-oil (60 to 70\%), biochar (15 to

$1325 \%$ ), and non-condensed gases (10 to $20 \%$ ). Microalgae biomass contain high moisture content,

14 thus it needs to go through the drying process before subjecting to pyrolysis [142]. Miao et al.

15 [143] achieved almost 18-24\% bio-oil yield for Chlorella prothothecoides and Microcystis

16 aeruginosa through fast pyrolysis [143].

\section{4.1.1.1.4 Combustion}

18 In all thermochemical process, combustion is one the easiest ways of producing energy.

19 The fuel is burnt, typically, in excess air. in which fuel react in the presence of air known as

20 burning. The major products are $\mathrm{CO}_{2}, \mathrm{H}_{2} \mathrm{O}$, and release of heat. Combustion usually occurs at a

21 high temperature above $800{ }^{\circ} \mathrm{C}$. It usually occurs in the boiler, furnaces where steam is generated

22 to produce electricity [144]. According to the life cycle assessment (LCA) combustion of algae, 
1 biomass leads to the lower $\mathrm{CO}_{2}$ emissions. However, further investigation and modified burner to

2 deal algae are required for further scale-up of the technology [145].

3 Table 8 Thermochemical technologies and lipid productivity

\begin{tabular}{llllll}
\hline Microalgae species & Process & $\begin{array}{l}\text { Temperature } \\
\left({ }^{\circ} \mathrm{C}\right)\end{array}$ & $\begin{array}{l}\text { Pressure } \\
(\mathrm{MPa})\end{array}$ & $\begin{array}{l}\text { Lipid Productivity } \\
(\% \text { dry wt. })\end{array}$ & Reference \\
\hline Botryococcus braunii & Liquefaction & 300 & 3 & 64 & {$[34]$} \\
Dunaliella tertiolecta & Liquefaction & 300 & 3 & 42 & {$[146]$} \\
Chlorella prothothecoides & Pyrolysis & 450 & 0.101 & 57.9 & [143] \\
Chlorella prothothecoides & Pyrolysis & 450 & 0.101 & 16.6 & \\
Chlorella prothothecoides & Pyrolysis & 500 & 0.101 & 18 & [141] \\
Chlorella prothothecoides & Pyrolysis & 500 & 0.101 & 24 & 55.3 \\
Chlorella prothothecoides & Pyrolysis & 502 & 0.101 & & \\
\hline
\end{tabular}

4

\section{$5 \quad$ 4.1.1.2 Biochemical conversion}

6 Biomass conversion through the biological process (e.g. anaerobic digestion, fermentation, 7 and transesterification) is used to produce biofuels.

\section{4.1.1.2.1 Anaerobic digestion (AD)}

9 In this process, organic matter is converted into gas and energy content. AD process is one

10 the most efficient method for higher moisture feed and is best suited for wet algal biomass. This

11 process is divided into three stages: hydrolysis, fermentation, and methanogenesis [147]. Complex

12 compounds are broken into soluble sugars in the first stage. It is followed by fermentation where

13 soluble sugar converts into alcohols, acetic acid and gaseous products mainly hydrogen and carbon

14 dioxide. These gases are metabolized into methane and carbon dioxide by methanogens during the

15 third stage $[148,149]$. Yen and Brune [150] experimentally showed that AD of combined waste 
1 of paper and algal biomass significantly increased methane production. Methane production rate

2 was doubled by using 50\% waste paper in algal biomass instead of pure algal biomass. However,

3 the products have about 20 to $40 \%$ of less heating value.

\section{$4 \quad$ 4.1.1.2.2 Fermentation}

Starch or cellulose are converted into alcohols like bioethanol in fermentation [144].

6 Mostly, yeast is used to convert sugars into ethanol. Distillation is required for separation of 7 products and purification of alcohols [151]. The residue from fermentation can be reused in 8 gasification. This reduces the process cost and makes this process economically more viable.

9 [132]. Microalgae like Chlorella Vulgaris are the most common species to produce ethanol due to

10 high starch content, and maximum ethanol conversion of 65\% reported [152]. Ueno et al. [153]

11 reported that conversion of algal biomass through dark fermentation process provided ethanol

12 productivity of $450 \mu \mathrm{mol} / \mathrm{g}$ dry wt. at $30{ }^{\circ} \mathrm{C}$.

\section{4.1.1.2.3 Photo-biological process}

14 Hydrogen is a clean and efficient energy carrier. Microalgae have necessary enzymatic

15 characteristics to produce hydrogen gas [154]. During photosynthesis of microalgae, molecules of 16 water are converted into oxygen and hydrogen ions under anaerobic conditions. Eukaryotic

17 microalgae are used for this process than hydrogenase enzymes, which convert hydrogen ions into

18 hydrogen gas [147]. Fundamentally, photosynthesis of hydrogen production occurs by two

19 processes. In the first process, hydrogen synthesis process divided into two parts, (1) algae is grown

20 at normal condition and (2) anaerobic conditions are introduced in microalgae which stimulate

21 continuous hydrogen production. The advantage of this process is that it does not generate harmful

22 or toxic chemicals. Moreover, it provides useful byproducts as a result of biomass[155]. 
Photo-biological process can also produce hydrogen and oxygen through photosynthesis

2 simultaneously. In this method, photosynthetic $\mathrm{H}_{2} \mathrm{O}$ oxidation electron is released. The electron is

3 directly fed into the hydrogenase-mediated $\mathrm{H}_{2}$-evolution process [154]. This process has greater

4 efficiency than two-step process because of simultaneous production. Melis and Happe [156]

5 studied that theoretical yield through two-step process for hydrogen gas production was 198

$6 \mathrm{~kg} / \mathrm{h} /$ day $[156]$.

\section{4.1.1.2.4 Transesterification}

8 In transesterification process [157], an alkoxy group of an ester is substituted by alcohol.

9 The reaction is reversible in nature in which triglycerides and methanol react in the presence of a

10 catalyst to produce biodiesel [158]. Miao and Wu [77] studied Chlorella protothecoides for

11 biodiesel production through conventional process. The reaction occurs at $30{ }^{\circ} \mathrm{C}$ and at a molar

12 ratio of oil to methanol is 56:1. The efficiency of transesterification process for biodiesel

13 production was determined for Chlorella vulgaris, Rhizoclonium hieroglyphicum, and mixed algae

14 culture. The results indicated higher conversion for Chlorella vulgaris with $95 \%$ and than mixed

15 algae culture, Rhizoclonium hieroglyphicum with $92 \%$ and $91 \%$ respectively [159].

\section{$16 \quad 4.2$ Commercial applications of algal biomass}

17 Microalgae have several commercial applications as shown in Fig. 6. Mostly these are

18 phototrophic in nature, which gives significant technical and commercial advantages such as food

19 food nutrition. Wastewater grown microalgae have numerous applications in fuel as discussed

20 above. But it also has numerous non-fuel applications such as fertilizer, cosmetics, and animal

21 feed. The production of biochar from microalgae as a result of many technologies such as pyrolysis

22 has great potential for fertilizer and carbon sequestration as an agricultural application [160]. It 
1 can also be used in bioenergy conversion as a process fuel. For carbon sequestration purposes, it

2 reduced carbon emission up to $84 \%$ [161].

3 A limited number of microalgae biomass is allowed for human consumption. Few species

4 such as Spirulina, Dunaliella and Chlorella are available in the market. These species dominate

5 the microalgae world market and they are available in the form of powder and tablets as food

6 additives. It is also used in medical application such as curing growth promotion of intestinal

7 Lactobacillus and renal failure [162]. Use of microalgae as food nutrition have some adverse

8 effects like Alzheimer's and Lou Gehrig's disease (ALS) due to ingestion of cyanobacteria mostly

9 present in Spirulina [163].

$10 \quad$ Chlorella and Arthrospira have commonly used microalgae species in cosmetics

11 industries, mostly in skin care products like anti-irritants in peelers and anti-aging creams.

12 Microalgae extensively are employed in sun and hair care products. A commercial example of

13 microalgae products and their properties is $C$. vulgaris, which stimulates collagen synthesis in the

14 skin by providing support to tissues regeneration and also helps in wrinkle reduction. Arthrospira

15 helps to minimize the early aging signs and also helps to lighten the skin [164]. 


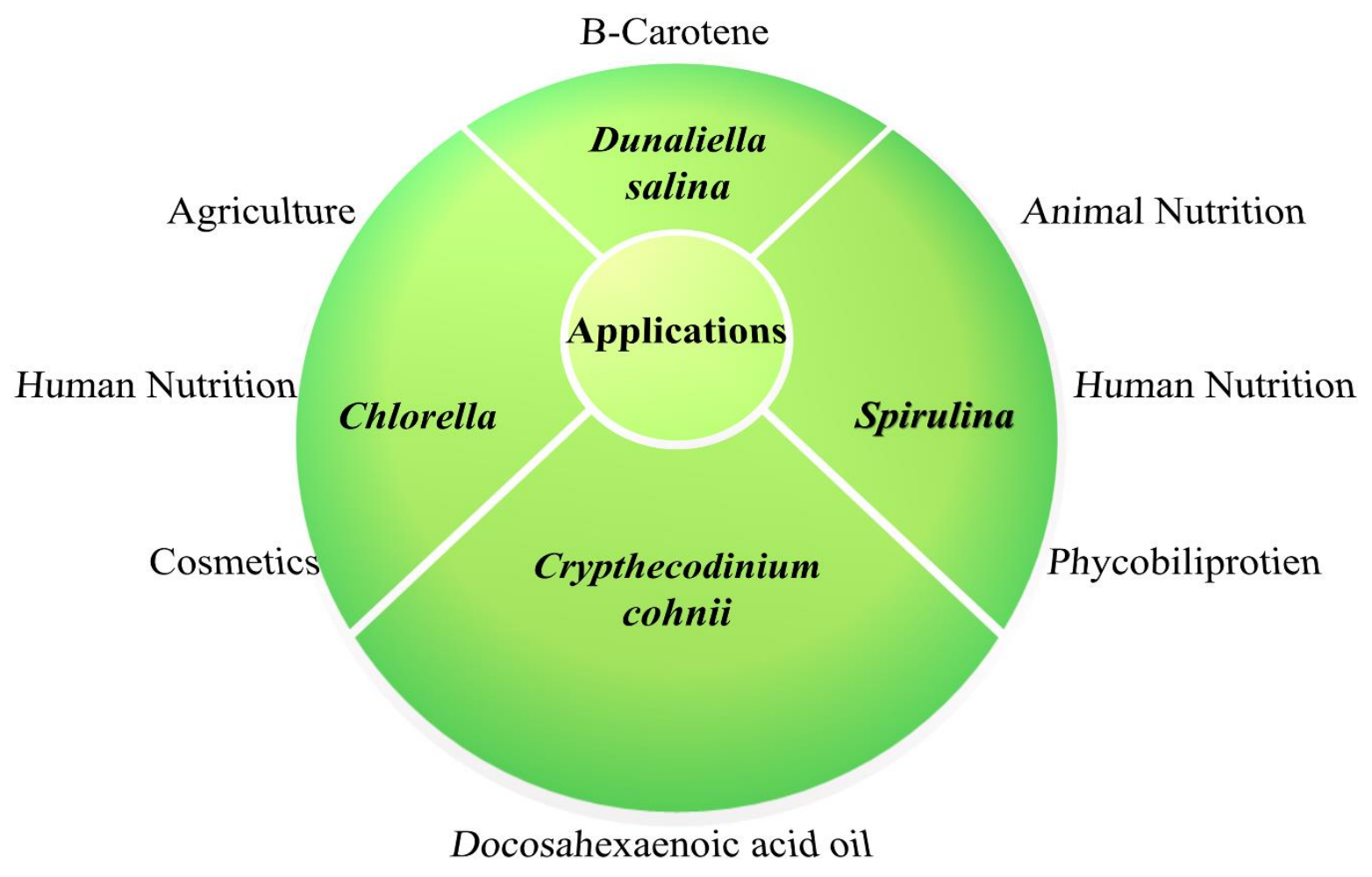

Fig 6. Applications of commercially used microalgae

Microalgae can be used for the synthesis of animal feed supplements. Microalgae present

4 in animal feed have multiple benefits such as improved fertility, healthier skin, increased

5 immunity, and better weight control. However, prolonged feeding of this supplement can also have

6 an adverse effect due to cyanobacteria. Mostly, Scenedesmus, Spirulina, and Chlorella have been

7 used in animal supplement. Algae are also used as a natural food source for many aquatic species

8 like fish, shrimps, and molluscs. The major applications of algae in aquaculture are fish feed. It

9 increase the immunity of fish and stabilize the quality of culture medium [165]. Comparison of

10 different commercial produced microalgae and their costs are summaries in Table 9. 
$1 \quad$ Table 9 Microalgae annual production and their prices [124]

\begin{tabular}{|c|c|c|c|}
\hline Microalgae Species & Production & & Price $(€ / \mathrm{kg})$ \\
\hline Spirulina & 3000 ton/year & - & 36 \\
\hline Chlorella & 2000 ton/year & - & 36 \\
\hline Dunaliella salina & 1200 ton/year & - & $215-2150$ \\
\hline Crypthecodinium cohnii & 240 ton/year & - & 43000 \\
\hline
\end{tabular}

Polyunsaturated fatty acid (PUFAs) is one of the vital roles of human development and

4 physiology [166]. The major advantage of PUFAs is to minimize the risk of cardiovascular disease.

5 At present, fish oils are used as the main source of PUFA, but its implementations are limited in

6 food additives due to fish odor, unpleasant taste, the presence of mixed fatty acid and poor

7 oxidative stability. Microalgae PUFA is used in many other commercial applications such as an

8 additive in infant milk and used in chicken feed to produce eggs enriched with omega-3 [167].

\section{Review of Techno-economic and life cycle analysis}

10 There are many challenges for the commercialization of algal biomass for bioenergy

11 production such as high operating and capital cost. To understand the current scenario, many

12 studies have been concluded for both open pond and photobioreactors. To find the way for

13 reducing costs, a brief economic analysis was performed by Davis et al. [168]. \$8.52/gal for 25

$14 \mathrm{~g} / \mathrm{m}^{2} /$ day were achieved for open system and cost for photobioreactor achieved $\$ 18.10 /$ gal for 1.25

$15 \mathrm{~kg} / \mathrm{m}^{3} /$ day, which provided biodiesel cost of $\$ 9.84 / \mathrm{gal}$, $\$ 20.53 / \mathrm{gal}$ for open bond and 16 photobioreactor, respectively [168]. Therefore, current microalgae biodiesel price is not 17 compatible as compared to fossil fuels for large-scale biofuel production. 
The major reason of cost intensiveness of microalgae biofuels, is nutrients ( $\mathrm{N}$ and $\mathrm{K}$ ) and

2 freshwater microalgae cultivation. This is almost 20 to $30 \%$ of total costs of biodiesel production

3 for microalgae $[12,169,170]$. Use of wastewater for microalgae growth has been proposed to be

4 the most economical and sustainable option for biofuel production on a commercial scale [12, 18 ,

$519,22]$. For example, all required nutrients can be supplied by wastewater due to which not only

6 cultivation cost is reduced but also wastewater can be treated simultaneously. Moreover,

7 significantly higher biomass and liquid contents can be achieved if inorganic wastewater is used

8 for algae cultivation through mixotrophic cultivation. Therefore, wastewater-based biofuel can

9 reduce the cost upto $50 \%$ making it comparable to petroleum diesel.

10 Besides the economic advantages of wastewater-based algae cultivation, it also reduces the

11 ecological footprint. Many studies have been published for LCA, using wastewater for the

12 production of biofuel. Use of wastewater was found to be more sustainable and environmentally

13 friendly. For example, Clarens et al [12] performed LCA for microalgae, corn, grass, and canola.

14 It suggested that wastewater based microalgae cultivation offset the environmental burdens related

15 to microalgae [12]. Another study was conducted by Yang et al [171], which indicated that by

16 using wastewater for microalgae, $90 \%$ of freshwater can be saved. In addition, nitrogen

17 consumption reduced to $94 \%$ and other nutrients such as sulfur, potassium, and magnesium,

18 reduced $100 \%$.

19 The life cycle of microalgae cultivation is shown in Fig.7. The use of wastewater for

20 microalgal cultivation is also difficult to process due to a variety of wastewater streams.

21 Wastewater location, pretreatment methods, and nutrients inculcates uncertainties for the

22 production of algal-biomass. Such as nutrients content in wastewater are unsuitable for microalgae,

23 incompatible for carbon to nitrogen ratio, presence of inhibitors, resulting in reduced process 
1 efficiency and low biomass production [172]. Due to which, downstream processing might

2 increase and as a result cost of the process can increase.

Fig 7. The life cycle of biofuel from microalgae

Recently, Mu et al. [173] studied multiple ways for wastewater based algal biofuels

6 including (1) cultivation methods for algae in open pond or bioreactors; (2) different conversion

7 technologies for biomass; (3) nutrient sources [173]. The results indicated that microalgal biofuel

8 production through wastewater was better than freshwater microalgal biofuels. However, the

9 effectiveness of this process was greatly dependent on nutrient profile and downstream processing.

10 The availability of suitable wastewater also restricted the implementation of these processes on a

11 large scale. Due to which further improvements are needed in current production technologies

12 before their commercial implementations. 


\section{Conclusions and future perspectives}

2 This review presents critical prospects of adopting an integrated approach to advocate the 3 sustainability of microalgae bio-refinery. It is argued that microalgae have meritorious attributes

4 to treat wastewater, produce energy, and recover value-added bio-products at the same time. These

5 have the potential to replace conventional fuel resources; however, the entire chain of microalgae

6 bioprocessing need improvements to prove their sustainability. The techno-economic analysis

7 reveals that the major cost of microalgae cultivation is rendered on nutrients supply. Wastewater

8 can source the nutrients to feed microalgae. A wide variety of wastewaters can be employed for

9 microalgae cultivation. Microalgae require a specific nutrients composition and concentration to

10 grow. The major challenge in using wastewater is the dilution, which would demand an additional

11 cost for water supply. Therefore, the wastewater satisfying the microalgae nutrients demand should

12 be identified, so that the dilution cost could be eliminated. The cultivation cost can be reduced by

13 increasing the biomass productivity. To this end, mixotrophic cultivation seems a promising

14 choice. Hybrid cultivation which involves cultivation in the close pond, as well as open pond

15 system, can receive attention in future since it offers high biomass productivity by controlling

16 contamination. Cascade cultivation should be attempted as it reduces resource input supplied in

17 the form of light, nutrients, and water.

18 In harvesting, bio-flocculation and auto-flocculation should be exploited, as

19 auto-flocculation is induced by the polysaccharides, which are abundantly available in

20 wastewaters. The scope of auto-flocculation should be extended to an attached-cultivation system

21 in which the microalgae are grown on a solid surface avoiding the complexity of an aqueous

22 medium. Microalgae cultivation in membrane photobioreactors can also displace the need for

23 dewatering. This study also points out the pyrolysis and liquefaction can be effective routes to 
1 extract bio-products from the microalgae biomass. It is concluded that the focus of microalgae bio-

2 refinery should be re-directed towards resource recovery and value-added products instead of

3 relying on traditional bio-processing of microalgae. Forward-looking steps should be taken to

4 project the scalability and sustainability of the proposed integrated system.

\section{Acknowledgment}

6 This work was funded by Higher Education Commission (HEC) under NRPU program project

7 number 20-3982/14 and 20-4547/14.

8

9

10

11

12

13

14

15

16

17

18 


\section{References}

[1] Ramachandra T, Mahapatra DM, Gordon R. Milking diatoms for sustainable energy: biochemical engineering versus gasoline-secreting diatom solar panels. Industrial \& Engineering Chemistry Research 2009;48(19):8769-88.

[2] Demirbas A. Progress and recent trends in biodiesel fuels. Energy conversion and management 2009;50(1):14-34.

[3] Wijffels RH, Barbosa MJ. An outlook on microalgal biofuels. Science 2010;329(5993):796-9.

[4] Atabani A, Shobana S, Mohammed M, Uğuz G, Kumar G, Arvindnarayan S, et al. Integrated valorization of waste cooking oil and spent coffee grounds for biodiesel production: Blending with higher alcohols, FT-IR, TGA, DSC and NMR characterizations. Fuel 2019;244:419-30.

[5] Elrayies GM. Microalgae: prospects for greener future buildings. Renewable and Sustainable Energy Reviews 2018;81:1175-91.

[6] Maaz M, Yasin M, Aslam M, Kumar G, Atabani AE, Idrees M, et al. Anaerobic membrane bioreactors for wastewater treatment: Novel configurations, fouling control and energy considerations. Bioresource technology 2019;283:358-72.

[7] Khalid A, Aslam M, Qyyum MA, Faisal A, Khan AL, Ahmed F, et al. Membrane separation processes for dehydration of bioethanol from fermentation broths: Recent developments, challenges, and prospects. Renewable and Sustainable Energy Reviews 2019;105:427-43.

[8] Saqib S, Rafiq S, Chawla M, Saeed M, Muhammad N, Khurram S, et al. Facile CO2 Separation in Composite Membranes. Chemical Engineering \& Technology 2019;42(1):30-44.

[9] Charfi A, Park E, Aslam M, Kim J. Particle-sparged anaerobic membrane bioreactor with fluidized polyethylene terephthalate beads for domestic wastewater treatment: Modelling approach and fouling control. Bioresource technology 2018;258:263-9.

[10] Charfi A, Thongmak N, Benyahia B, Aslam M, Harmand J, Amar NB, et al. A modelling approach to study the fouling of an anaerobic membrane bioreactor for industrial wastewater treatment. Bioresource technology 2017;245:207-15.

[11] Aslam M, Yang P, Lee P-H, Kim J. Novel staged anaerobic fluidized bed ceramic membrane bioreactor: Energy reduction, fouling control and microbial characterization. Journal of Membrane Science 2018;553:200-8.

[12] Clarens AF, Resurreccion EP, White MA, Colosi LM. Environmental life cycle comparison of algae to other bioenergy feedstocks. Environmental science \& technology 2010;44(5):1813-9.

[13] Green FB, Lundquist T, Oswald W. Energetics of advanced integrated wastewater pond systems. Water Science and Technology 1995;31(12):9-20.

[14] Oswald W. J. Gotaas, H. B., Golueke, CG. Kellen, W R-Algae in Waste Treatment, Sewage and Industrial Wastes 1957;29(4):437.

[15] Park J, Craggs R, Shilton A. Wastewater treatment high rate algal ponds for biofuel production. Bioresource technology 2011;102(1):35-42.

[16] Oswald WJ, Golueke CG. Biological transformation of solar energy. Advances in applied microbiology. Elsevier; 1960;2:223-62. 
[17] Lau P, Tam N, Wong Y. Effect of algal density on nutrient removal from primary settled wastewater. Environmental Pollution 1995;89(1):59-66.

[18] Sheehan J, Dunahay T, Benemann J, Roessler P. A look back at the US Department of Energy's aquatic species program: biodiesel from algae. National Renewable Energy Laboratory 1998;328.

[19] Zhou W, Li Y, Min M, Hu B, Chen P, Ruan R. Local bioprospecting for high-lipid producing microalgal strains to be grown on concentrated municipal wastewater for biofuel production. Bioresource Technology 2011;102(13):6909-19.

[20] Li Y, Chen Y-F, Chen P, Min M, Zhou W, Martinez B, et al. Characterization of a microalga Chlorella sp. well adapted to highly concentrated municipal wastewater for nutrient removal and biodiesel production. Bioresource technology 2011;102(8):5138-44.

[21] Zhou W, Cheng Y, Li Y, Wan Y, Liu Y, Lin X, et al. Novel fungal pelletization-assisted technology for algae harvesting and wastewater treatment. Applied biochemistry and biotechnology 2012;167(2):214-28.

[22] Zhou W, Li Y, Min M, Hu B, Zhang H, Ma X, et al. Growing wastewater-born microalga Auxenochlorella protothecoides UMN280 on concentrated municipal wastewater for simultaneous nutrient removal and energy feedstock production. Applied Energy 2012;98:433-40.

[23] Zhou W, Min M, Li Y, Hu B, Ma X, Cheng Y, et al. A hetero-photoautotrophic two-stage cultivation process to improve wastewater nutrient removal and enhance algal lipid accumulation. Bioresource Technology 2012;110:448-55.

[24] Li Y, Zhou W, Hu B, Min M, Chen P, Ruan RR. Effect of light intensity on algal biomass accumulation and biodiesel production for mixotrophic strains Chlorella kessleri and Chlorella protothecoide cultivated in highly concentrated municipal wastewater. Biotechnology and bioengineering 2012;109(9):2222-9.

[25] Min M, Wang L, Li Y, Mohr MJ, Hu B, Zhou W, et al. Cultivating Chlorella sp. in a pilotscale photobioreactor using centrate wastewater for microalgae biomass production and wastewater nutrient removal. Applied biochemistry and biotechnology 2011;165(1):12337.

[26] Wang L, Li Y, Chen P, Min M, Chen Y, Zhu J, et al. Anaerobic digested dairy manure as a nutrient supplement for cultivation of oil-rich green microalgae Chlorella sp. Bioresource technology 2010;101(8):2623-8.

[27] Min M, Hu B, Mohr MJ, Shi A, Ding J, Sun Y, et al. Swine manure-based pilot-scale algal biomass production system for fuel production and wastewater treatment - a case study. Applied biochemistry and biotechnology 2014;172(3):1390-406.

[28] Zhou W, Chen P, Min M, Ma X, Wang J, Griffith R, et al. Environment-enhancing algal biofuel production using wastewaters. Renewable and Sustainable Energy Reviews 2014;36:256-69.

[29] Xiong W, Gao C, Yan D, Wu C, Wu Q. Double CO2 fixation in photosynthesisfermentation model enhances algal lipid synthesis for biodiesel production. Bioresource technology 2010;101(7):2287-93.

[30] Hu B, Min M, Zhou W, Du Z, Mohr M, Chen P, et al. Enhanced mixotrophic growth of microalga Chlorella sp. on pretreated swine manure for simultaneous biofuel feedstock production and nutrient removal. Bioresource technology 2012;126:71-9. 
[31] Rodolfi L, Chini Zittelli G, Bassi N, Padovani G, Biondi N, Bonini G, et al. Microalgae for oil: Strain selection, induction of lipid synthesis and outdoor mass cultivation in a low-cost photobioreactor. Biotechnology and bioengineering 2009;102(1):100-12.

[32] Gouveia L, Oliveira AC. Microalgae as a raw material for biofuels production. Journal of industrial microbiology \& biotechnology 2009;36(2):269-74.

[33] Weldy CS, Huesemann M. Lipid production by Dunaliella salina in batch culture: effects of nitrogen limitation and light intensity. US Department of Energy Journal of Undergraduate Research 2007;7(1):115-22.

[34] Dote Y, Sawayama S, Inoue S, Minowa T, Yokoyama S-y. Recovery of liquid fuel from hydrocarbon-rich microalgae by thermochemical liquefaction. Fuel 1994;73(12):1855-7.

[35] Sawayama S, Minowa T, Yokoyama S-Y. Possibility of renewable energy production and $\mathrm{CO} 2$ mitigation by thermochemical liquefaction of microalgae. Biomass and Bioenergy 1999;17(1):33-9.

[36] Chiu S-Y, Kao C-Y, Tsai M-T, Ong S-C, Chen C-H, Lin C-S. Lipid accumulation and CO2 utilization of Nannochloropsis oculata in response to $\mathrm{CO} 2$ aeration. Bioresource technology 2009;100(2):833-8.

[37] Kim S-K. Handbook of marine microalgae: biotechnology advances. Academic Press; 2015.

[38] Mata TM, Martins AA, Caetano NS. Microalgae for biodiesel production and other applications: a review. Renewable and sustainable energy reviews 2010;14(1):217-32.

[39] Janssen M, Tramper J, Mur LR, Wijffels RH. Enclosed outdoor photobioreactors: Light regime, photosynthetic efficiency, scale-up, and future prospects. Biotechnology and bioengineering 2003;81(2):193-210.

[40] Pulz O, Scheibenbogen K. Photobioreactors: design and performance with respect to light energy input. Bioprocess and algae reactor technology, apoptosis. Springer; 1998;59: 12352.

[41] Wang B, Li Y, Wu N, Lan CQ. CO2 bio-mitigation using microalgae. Applied microbiology and biotechnology 2008;79(5):707-18.

[42] Fazal T, Mushtaq A, Rehman F, Khan AU, Rashid N, Farooq W, et al. Bioremediation of textile wastewater and successive biodiesel production using microalgae. Renewable and Sustainable Energy Reviews 2018;82:3107-26.

[43] Borowitzka MA. Microalgae for aquaculture: opportunities and constraints. Journal of Applied Phycology 1997;9(5):393.

[44] Chisti Y. Biodiesel from microalgae Biotechnology Advances 2007;25:294-306.

[45] Andersen R. Recipes for freshwater and seawater media. Algal culturing techniques 2005.

[46] Posten C. Design principles of photo-bioreactors for cultivation of microalgae. Engineering in Life Sciences 2009;9(3):165-77.

[47] Molina E, Fernández J, Acién F, Chisti Y. Tubular photobioreactor design for algal cultures. Journal of biotechnology 2001;92(2):113-31.

[48] Sierra E, Acién F, Fernández J, García J, González C, Molina E. Characterization of a flat plate photobioreactor for the production of microalgae. Chemical Engineering Journal 2008;138(1-3):136-47.

[49] Slegers P, Wijffels R, Van Straten G, Van Boxtel A. Design scenarios for flat panel photobioreactors. Applied energy 2011;88(10):3342-53.

[50] Eriksen NT. The technology of microalgal culturing. Biotechnology letters 2008;30(9):1525-36. 
[51] Samson R, Leduy A. Multistage continuous cultivation of blue-green alga spirulina maxima in the flat tank photobioreactors with recycle. The Canadian Journal of Chemical Engineering 1985;63(1):105-12.

[52] Hu Q, Kurano N, Kawachi M, Iwasaki I, Miyachi S. Ultrahigh-cell-density culture of a marine green alga Chlorococcum littorale in a flat-plate photobioreactor. Applied Microbiology and Biotechnology 1998;49(6):655-62.

[53] Richmond A. Microalgal biotechnology at the turn of the millennium: a personal view. Journal of Applied Phycology 2000;12(3-5):441-51.

[54] Richmond A, Cheng-Wu Z, Zarmi Y. Efficient use of strong light for high photosynthetic productivity: interrelationships between the optical path, the optimal population density and cell-growth inhibition. Biomolecular Engineering 2003;20(4-6):229-36.

[55] Olaizola M. Commercial production of astaxanthin from Haematococcus pluvialis using 25,000-liter outdoor photobioreactors. Journal of Applied Phycology 2000;12(3-5):499506.

[56] Pulz O. Photobioreactors: production systems for phototrophic microorganisms. Applied microbiology and biotechnology 2001;57(3):287-93.

[57] Chang H-X, Fu Q, Huang Y, Xia A, Liao Q, Zhu X, et al. An annular photobioreactor with ion-exchange-membrane for non-touch microalgae cultivation with wastewater. Bioresource technology 2016;219:668-76.

[58] Kumar A, Yuan X, Sahu AK, Dewulf J, Ergas SJ, Van Langenhove H. A hollow fiber membrane photo-bioreactor for $\mathrm{CO} 2$ sequestration from combustion gas coupled with wastewater treatment: a process engineering approach. Journal of Chemical Technology \& Biotechnology 2010;85(3):387-94.

[59] Honda R, Boonnorat J, Chiemchaisri C, Chiemchaisri W, Yamamoto K. Carbon dioxide capture and nutrients removal utilizing treated sewage by concentrated microalgae cultivation in a membrane photobioreactor. Bioresource technology 2012;125:59-64.

[60] Singh G, Thomas PB. Nutrient removal from membrane bioreactor permeate using microalgae and in a microalgae membrane photoreactor. Bioresource technology 2012;117:80-5.

[61] Bilad M, Discart V, Vandamme D, Foubert I, Muylaert K, Vankelecom IF. Coupled cultivation and pre-harvesting of microalgae in a membrane photobioreactor (MPBR). Bioresource technology 2014;155:410-7.

[62] Rossignol N, Lebeau T, Jaouen P, Robert J. Comparison of two membranephotobioreactors, with free or immobilized cells, for the production of pigments by a marine diatom. Bioprocess Engineering 2000;23(5):495-501.

[63] Marbelia L, Bilad MR, Passaris I, Discart V, Vandamme D, Beuckels A, et al. Membrane photobioreactors for integrated microalgae cultivation and nutrient remediation of membrane bioreactors effluent. Bioresource technology 2014;163:228-35.

[64] Rubio FC, Fernández FA, Pérez JS, Camacho FG, Grima EM. Prediction of dissolved oxygen and carbon dioxide concentration profiles in tubular photobioreactors for microalgal culture. Biotechnology and Bioengineering 1999;62(1):71-86.

[65] Fernández FA, Sevilla JF, Pérez JS, Grima EM, Chisti Y. Airlift-driven external-loop tubular photobioreactors for outdoor production of microalgae: assessment of design and performance. Chemical Engineering Science 2001;56(8):2721-32. 
[66] Ugwu C, Ogbonna J, Tanaka H. Improvement of mass transfer characteristics and productivities of inclined tubular photobioreactors by installation of internal static mixers. Applied microbiology and biotechnology 2002;58(5):600-7.

[67] Carlozzi P. Dilution of solar radiation through "culture" lamination in photobioreactor rows facing south-north: a way to improve the efficiency of light utilization by cyanobacteria (Arthrospira platensis). Biotechnology and bioengineering 2003;81(3):30515.

[68] Hall DO, Acién Fernández F, Guerrero EC, Rao KK, Grima EM. Outdoor helical tubular photobioreactors for microalgal production: modeling of fluid-dynamics and mass transfer and assessment of biomass productivity. Biotechnology and bioengineering 2003;82(1):62-73.

[69] López MG-M, Sanchez EDR, López JC, Fernández FA, Sevilla JF, Rivas J, et al. Comparative analysis of the outdoor culture of Haematococcus pluvialis in tubular and bubble column photobioreactors. Journal of biotechnology 2006;123(3):329-42.

[70] Converti A, Lodi A, Del Borghi A, Solisio C. Cultivation of Spirulina platensis in a combined airlift-tubular reactor system. Biochemical Engineering Journal 2006;32(1):138.

[71] Cheng-Wu Z, Zmora O, Kopel R, Richmond A. An industrial-size flat plate glass reactor for mass production of Nannochloropsis sp.(Eustigmatophyceae). Aquaculture 2001;195(1-2):35-49.

[72] Secchi S, Kurkalova L, Gassman PW, Hart C. Land use change in a biofuels hotspot: the case of Iowa, USA. Biomass and Bioenergy 2011;35(6):2391-400.

[73] Zittelli GC, Rodolfi L, Biondi N, Tredici MR. Productivity and photosynthetic efficiency of outdoor cultures of Tetraselmis suecica in annular columns. Aquaculture 2006;261(3):932-43.

[74] Sato T, Usui S, Tsuchiya Y, Kondo Y. Invention of outdoor closed type photobioreactor for microalgae. Energy conversion and management 2006;47(6):791-9.

[75] Huntley ME, Redalje DG. CO 2 mitigation and renewable oil from photosynthetic microbes: a new appraisal. Mitigation and adaptation strategies for global change 2007;12(4):573-608.

[76] Chen F, Zhang Y, Guo S. Growth and phycocyanin formation of Spirulina platensis in photoheterotrophic culture. Biotechnology letters 1996;18(5):603-8.

[77] Miao X, Wu Q. Biodiesel production from heterotrophic microalgal oil. Bioresource technology 2006;97(6):841-6.

[78] Eriksen NT. Production of phycocyanin - a pigment with applications in biology, biotechnology, foods and medicine. Applied microbiology and biotechnology 2008;80(1):1-14.

[79] Chen G-Q, Chen F. Growing phototrophic cells without light. Biotechnology letters 2006;28(9):607-16.

[80] De Swaaf ME, Sijtsma L, Pronk JT. High-cell-density fed-batch cultivation of the docosahexaenoic acid producing marine alga Crypthecodinium cohnii. Biotechnology and bioengineering 2003;81(6):666-72.

[81] $\mathrm{Li} \mathrm{X}, \mathrm{Xu} \mathrm{H}, \mathrm{Wu} \mathrm{Q}$. Large-scale biodiesel production from microalga Chlorella protothecoides through heterotrophic cultivation in bioreactors. Biotechnology and bioengineering 2007;98(4):764-71. 
[82] Xiong W, Li X, Xiang J, Wu Q. High-density fermentation of microalga Chlorella protothecoides in bioreactor for microbio-diesel production. Applied microbiology and biotechnology 2008;78(1):29-36.

[83] Zhang X-W, Zhang Y-M, Chen F. Application of mathematical models to the determination optimal glucose concentration and light intensity for mixotrophic culture of Spirulina platensis. Process Biochemistry 1999;34(5):477-81.

[84] Andrade MR, Costa JA. Mixotrophic cultivation of microalga Spirulina platensis using molasses as organic substrate. Aquaculture 2007;264(1-4):130-4.

[85] Chojnacka K, Noworyta A. Evaluation of Spirulina sp. growth in photoautotrophic, heterotrophic and mixotrophic cultures. Enzyme and Microbial Technology 2004;34(5):461-5.

[86] Grima EM, Belarbi E-H, Fernández FA, Medina AR, Chisti Y. Recovery of microalgal biomass and metabolites: process options and economics. Biotechnology advances 2003;20(7-8):491-515.

[87] Kumar H, Yadava P, Gaur J. Electrical flocculation of the unicellular green alga Chlorella vulgaris Beijerinck. Aquatic Botany 1981;11:187-95.

[88] Bernhardt H. Flocculation of micro-organisms. Aqua 1991;40(2):76-87.

[89] Divakaran R, Pillai VS. Flocculation of algae using chitosan. Journal of Applied Phycology 2002;14(5):419-22.

[90] Shah JH, Deokar A, Patel K, Panchal K, Mehta AV. A comprehensive overview on various method of harvesting microalgae according to indian perspective. International Conference on Multidisciplinary Research \& Practice. International Conference on Multidisciplinary Research \& Practice. 1. 2014:313-17.

[91] Chen P, Min M, Chen Y, Wang L, Li Y, Chen Q, et al. Review of biological and engineering aspects of algae to fuels approach. International Journal of Agricultural and Biological Engineering 2010;2(4):1-30.

[92] Uduman N, Qi Y, Danquah MK, Forde GM, Hoadley A. Dewatering of microalgal cultures: a major bottleneck to algae-based fuels. Journal of renewable and sustainable energy 2010;2(1):012701.

[93] Greenwell H, Laurens L, Shields R, Lovitt R, Flynn K. Placing microalgae on the biofuels priority list: a review of the technological challenges. Journal of the royal society interface 2010;7(46):703-26.

[94] Friedman A, Peaks D, Nichols R. Algae separation from oxidation pond effluents [Water pollution]. Proceedings-Industrial Wastes Conference, Purdue University (USA). 1977.

[95] Hanotu J, Bandulasena HH, Zimmerman WB. Microflotation performance for algal separation. Biotechnology and bioengineering 2012;109(7):1663-73.

[96] Javed F, Shamair Z, Ali S, Ahmad N, Hafeez A, Fazal T, et al. "Pushing and pulling" the equilibrium through bubble mediated reactive separation for ethyl acetate production. Reaction Chemistry \& Engineering 2019;4:705-14.

[97] Rehman F, Medley GJ, Bandulasena H, Zimmerman WB. Fluidic oscillator-mediated microbubble generation to provide cost effective mass transfer and mixing efficiency to the wastewater treatment plants. Environmental research 2015;137:32-9.

[98] Mouchet P, Bonnelye V. Solving algae problems: French expertise and world-wide applications. Journal of water supply: research and technology-AQUA 1998;47(3):125-41.

[99] Judd S. The MBR book: principles and applications of membrane bioreactors for water and wastewater treatment. Elsevier; 2010. 
[100] Vandamme D, Pontes SCV, Goiris K, Foubert I, Pinoy LJJ, Muylaert K. Evaluation of electro-coagulation-flocculation for harvesting marine and freshwater microalgae. Biotechnology and bioengineering 2011;108(10):2320-9.

[101] Rossi N, Jaouen P, Legentilhomme P, Petit I. Harvesting of cyanobacterium Arthrospira platensis using organic filtration membranes. Food and bioproducts processing 2004;82(3):244-50.

[102] Petrusevski B, Bolier G, Van Breemen A, Alaerts G. Tangential flow filtration: a method to concentrate freshwater algae. Water Research 1995;29(5):1419-24.

[103] Aslam M, Ahmad R, Kim J. Recent developments in biofouling control in membrane bioreactors for domestic wastewater treatment. Separation and Purification Technology 2018;206:297-315.

[104] Aslam M, Kim J. Investigating membrane fouling associated with GAC fluidization on membrane with effluent from anaerobic fluidized bed bioreactor in domestic wastewater treatment. Environmental science and pollution research international 2019;26(2):1170-80.

[105] Eliseus A, Bilad MR, Nordin NAHM, Khan AL, Putra ZA, Wirzal MDH, et al. Two-way switch: Maximizing productivity of tilted panel in membrane bioreactor. Journal of Environmental Management 2018;228:529-37.

[106] Ahmad R, Aslam M, Park E, Chang S, Kwon D, Kim J. Submerged low-cost pyrophyllite ceramic membrane filtration combined with GAC as fluidized particles for industrial wastewater treatment. Chemosphere 2018;206:784-92.

[107] Charfi A, Aslam M, Kim J. Modelling approach to better control biofouling in fluidized bed membrane bioreactor for wastewater treatment. Chemosphere 2018;191:136-44.

[108] Aslam M, Charfi A, Kim J. Membrane scouring to control fouling under fluidization of non-adsorbing media for wastewater treatment. Environmental Science and Pollution Research 2019;26(2):1061-71.

[109] Aslam M, Lee P-H, Kim J. Analysis of membrane fouling with porous membrane filters by microbial suspensions for autotrophic nitrogen transformations. Separation and Purification Technology 2015;146:284-93.

[110] Aslam M, McCarty PL, Bae J, Kim J. The effect of fluidized media characteristics on membrane fouling and energy consumption in anaerobic fluidized membrane bioreactors. Separation and Purification Technology 2014;132:10-5.

[111] Aslam M, Charfi A, Lesage G, Heran M, Kim J. Membrane bioreactors for wastewater treatment: a review of mechanical cleaning by scouring agents to control membrane fouling. Chemical Engineering Journal 2017;307:897-913.

[112] Ahmad R, Ahmad Z, Khan AU, Mastoi NR, Aslam M, Kim J. Photocatalytic systems as an advanced environmental remediation: Recent developments, limitations and new avenues for applications. Journal of Environmental Chemical Engineering 2016;4(4):414364.

[113] Rossignol N, Vandanjon L, Jaouen P, Quemeneur F. Membrane technology for the continuous separation microalgae/culture medium: compared performances of cross-flow microfiltration and ultrafiltration. Aquacultural Engineering 1999;20(3):191-208.

[114] Rossi N, Petit I, Jaouen P, Legentilhomme P, Derouiniot M. Harvesting of cyanobacterium Arthrospira platensis using inorganic filtration membranes. Separation science and technology 2005;40(15):3033-50. 
[115] Aslam M, Ahmad R, Yasin M, Khan AL, Shahid MK, Hossain S, et al. Anaerobic membrane bioreactors for biohydrogen production: Recent developments, challenges and perspectives. Bioresource technology 2018;269:452-64.

[116] Aslam M, McCarty PL, Shin C, Bae J, Kim J. Low energy single-staged anaerobic fluidized bed ceramic membrane bioreactor (AFCMBR) for wastewater treatment. Bioresource technology 2017;240:33-41.

[117] Shelef G, Sukenik A, Green M. Microalgae harvesting and processing: a literature review. Technion Research and Development Foundation Ltd., Haifa (Israel); 1984.

[118] Shen Y, Yuan W, Pei Z, Wu Q, Mao E. Microalgae mass production methods. Transactions of the ASABE 2009;52(4):1275-87.

[119] Lavoie A, De la Noüe J. Harvesting of Scenedesmus obliquus in wastewaters: Auto-or bioflocculation? Biotechnology and bioengineering 1987;30(7):852-9.

[120] Passow U, Alldredge AL. Aggregation of a diatom bloom in a mesocosm: The role of transparent exopolymer particles (TEP). Deep Sea Research Part II: Topical Studies in Oceanography 1995;42(1):99-109.

[121] Chawla M, Rafiq S, Jamil F, Usman MR, Khurram S, Ghauri M, et al. Hydrocarbons fuel upgradation in the presence of modified bi-functional catalyst. Journal of Cleaner Production 2018;198:683-92.

[122] Ghauri M, Bokhari A, Aslam M, Tufail M. Biogas reactor design for dry process and generation of electricity on sustainable basis. International Journal of Chemical and Environmental Engineering 2011;2(6):414-7.

[123] Gharieb Y, Ibrahim Z. Alternative Track of Energy in Egypt. International Institute of Social and Economic Sciences; 2014.

[124] Brennan L, Owende P. Biofuels from microalgae - a review of technologies for production, processing, and extractions of biofuels and co-products. Renewable and sustainable energy reviews 2010;14(2):557-77.

[125] Naik SN, Goud VV, Rout PK, Dalai AK. Production of first and second generation biofuels: a comprehensive review. Renewable and sustainable energy reviews 2010;14(2):578-97.

[126] Singh KK. Economic competitiveness of Paulownia as a feedstock for ethanol and electricity production. Tennessee State University; 2015.

[127] Mohammady NG, El-Sayed HS, Taha HM, Fakhry EM, Mahmoud NH, Mohamed JH, et al. Chlorella sp. as a Source of Biodiesel and By-Products: An Integral Study of Med-Algae Project; Part A. Int J TechnoChem Res 2015;1(3):144-51.

[128] Bravo IN, Velásquez-Orta S, Cuevas-García R, Monje-Ramirez I, Harvey A, Ledesma MO. Bio-crude oil production using catalytic hydrothermal liquefaction (HTL) from native microalgae harvested by ozone-flotation. Fuel 2019;241:255-63.

[129] Hu Y, Qi L, Feng S, Bassi A, Xu CC. Comparative studies on liquefaction of low-lipid microalgae into bio-crude oil using varying reaction media. Fuel 2019;238:240-7.

[130] Sekoai PT, Ouma CNM, Du Preez SP, Modisha P, Engelbrecht N, Bessarabov DG, et al. Application of nanoparticles in biofuels: An overview. Fuel 2019;237:380-97.

[131] Benemann JR, Weissman JC, Koopman BL, Oswald WJ. Energy production by microbial photosynthesis. Nature 1977;268(5615):19.

[132] Demirbaş A. Biomass resource facilities and biomass conversion processing for fuels and chemicals. Energy conversion and Management 2001;42(11):1357-78. 
[133] López-González D, Fernandez-Lopez M, Valverde J, Sanchez-Silva L. Comparison of the steam gasification performance of three species of microalgae by thermogravimetric-mass spectrometric analysis. Fuel 2014;134:1-10.

[134] Adnan MA, Xiong Q, Hidayat A, Hossain MM. Gasification performance of Spirulina microalgae-A thermodynamic study with tar formation. Fuel 2019;241:372-81.

[135] Hirano A, Hon-Nami K, Kunito S, Hada M, Ogushi Y. Temperature effect on continuous gasification of microalgal biomass: theoretical yield of methanol production and its energy balance. Catalysis Today 1998;45(1-4):399-404.

[136] $\mathrm{Hu}$ Y, Gong M, Xu CC, Bassi A. Investigation of an alternative cell disruption approach for improving hydrothermal liquefaction of microalgae. Fuel 2017;197:138-44.

[137] Minowa T, Sawayama S. A novel microalgal system for energy production with nitrogen cycling. Fuel 1999;78(10):1213-5.

[138] McKendry P. Energy production from biomass (part 3): gasification technologies. Bioresource technology 2002;83(1):55-63.

[139] Patil V, Tran K-Q, Giselrød HR. Towards sustainable production of biofuels from microalgae. International journal of molecular sciences 2008;9(7):1188-95.

[140] Goyal H, Seal D, Saxena R. Bio-fuels from thermochemical conversion of renewable resources: a review. Renewable and sustainable energy reviews 2008;12(2):504-17.

[141] Demirbaş A. Oily products from mosses and algae via pyrolysis. Energy Sources, Part A 2006;28(10):933-40.

[142] Amin S. Review on biofuel oil and gas production processes from microalgae. Energy conversion and management 2009;50(7):1834-40.

[143] Miao X, Wu Q. High yield bio-oil production from fast pyrolysis by metabolic controlling of Chlorella protothecoides. Journal of biotechnology 2004;110(1):85-93.

[144] McKendry P. Energy production from biomass (part 2): conversion technologies. Bioresource technology 2002;83(1):47-54.

[145] Kadam KL. Environmental implications of power generation via coal-microalgae cofiring. Energy 2002;27(10):905-22.

[146] Minowa T, Yokoyama S-y, Kishimoto M, Okakura T. Oil production from algal cells of Dunaliella tertiolecta by direct thermochemical liquefaction. Fuel 1995;74(12):1735-8.

[147] Cantrell KB, Ducey T, Ro KS, Hunt PG. Livestock waste-to-bioenergy generation opportunities. Bioresource technology 2008;99(17):7941-53.

[148] Olguín E. The cleaner production strategy applied to animal production. Environmental biotechnology and cleaner bioprocesses 2000:227-43.

[149] Yang P, Tan G-YA, Aslam M, Kim J, Lee P-H. Metatranscriptomic evidence for classical and $\mathrm{RuBisCO}$-mediated $\mathrm{CO} 2$ reduction to methane facilitated by direct interspecies electron transfer in a methanogenic system. Scientific reports 2019;9(1):4116.

[150] Yen H-W, Brune DE. Anaerobic co-digestion of algal sludge and waste paper to produce methane. Bioresource technology 2007;98(1):130-4.

[151] Shokrkar H, Ebrahimi S, Zamani M. Bioethanol production from acidic and enzymatic hydrolysates of mixed microalgae culture. Fuel 2017;200:380-6.

[152] Hirano A, Ueda R, Hirayama S, Ogushi Y. CO2 fixation and ethanol production with microalgal photosynthesis and intracellular anaerobic fermentation. Energy 1997;22(23):137-42. 
[153] Ueno Y, Kurano N, Miyachi S. Ethanol production by dark fermentation in the marine green alga, Chlorococcum littorale. Journal of Fermentation and Bioengineering 1998;86(1):38-43.

[154] Ghirardi ML, Zhang L, Lee JW, Flynn T, Seibert M, Greenbaum E, et al. Microalgae: a green source of renewable H2. Trends in biotechnology 2000;18(12):506-11.

[155] Melis A. Green alga hydrogen production: progress, challenges and prospects. International Journal of Hydrogen Energy 2002;27(11):1217-28.

[156] Melis A, Happe T. Hydrogen production. Green algae as a source of energy. Plant physiology 2001;127(3):740-8.

[157] Ahmad N, Javed F, Awan JA, Ali S, Fazal T, Hafeez A, et al. Biodiesel production intensification through microbubble mediated esterification. Fuel 2019;253:25-31.

[158] Nwokoagbara E, Olaleye AK, Wang M. Biodiesel from microalgae: The use of multicriteria decision analysis for strain selection. Fuel 2015;159:241-9.

[159] Ahmad F, Khan AU, Yasar A. Transesterification of oil extracted from different species of algae for biodiesel production. African Journal of Environmental Science and Technology 2013;7(6):358-64.

[160] Marris E. Putting the carbon back: Black is the new green. Nature Publishing Group; 2006;442:624-26.

[161] Lehmann J. A handful of carbon. Nature 2007;447:143-44.

[162] Yamaguchi K. Recent advances in microalgal bioscience in Japan, with special reference to utilization of biomass and metabolites: a review. Journal of applied phycology 1996;8(6):487-502.

[163] Cox PA, Banack SA, Murch SJ, Rasmussen U, Tien G, Bidigare RR, et al. Diverse taxa of cyanobacteria produce $\beta$-N-methylamino-L-alanine, a neurotoxic amino acid. Proceedings of the National Academy of Sciences 2005;102(14):5074-8.

[164] Stolz P. Manufacturing microalgae for skin care. Cosmetics Toiletries 2005;120:99-106.

[165] Chuntapa B, Powtongsook S, Menasveta P. Water quality control using Spirulina platensis in shrimp culture tanks. Aquaculture 2003;220(1-4):355-66.

[166] Hu C, Li M, Li J, Zhu Q, Liu Z. Variation of lipid and fatty acid compositions of the marine microalga Pavlova viridis (Prymnesiophyceae) under laboratory and outdoor culture conditions. World Journal of Microbiology and Biotechnology 2008;24(7):1209-14.

[167] Pulz O, Gross W. Valuable products from biotechnology of microalgae. Applied microbiology and biotechnology 2004;65(6):635-48.

[168] Davis R, Aden A, Pienkos PT. Techno-economic analysis of autotrophic microalgae for fuel production. Applied Energy 2011;88(10):3524-31.

[169] Benemann JR. Open ponds and closed photobioreactors-comparative economics. 5th Annual World Congress on Industrial Biotechnology and Bioprocessing. Chicago. 30. 2008.

[170] Chen C-Y, Yeh K-L, Aisyah R, Lee D-J, Chang J-S. Cultivation, photobioreactor design and harvesting of microalgae for biodiesel production: a critical review. Bioresource technology 2011;102(1):71-81.

[171] Yang J, Xu M, Zhang X, Hu Q, Sommerfeld M, Chen Y. Life-cycle analysis on biodiesel production from microalgae: water footprint and nutrients balance. Bioresource technology 2011;102(1):159-65.

[172] Cheung K, Chu L, Wong M. Toxic effect of landfill leachate on microalgae. Water, Air, and Soil Pollution 1993;69(3-4):337-49. 
[173] Mu D, Min M, Krohn B, Mullins KA, Ruan R, Hill J. Life cycle environmental impacts of wastewater-based algal biofuels. Environmental science \& technology 2014;48(19):11696704. 